\title{
"A renewal of the fraternal relations that shared blood and history demand": Latin American Painting, Spanish Exhibitions, and Public Display at the 1910 Independence Celebrations in Argentina, Chile, and Mexico
}

\section{Elizabeth Boone}

Volume 38, numéro 2, 2013

Contemporary Scholarship on Latin American Art

Approches contemporaines de l'art latino-américain

URI : https://id.erudit.org/iderudit/1020796ar

DOI : https://doi.org/10.7202/1020796ar

Aller au sommaire du numéro

Éditeur(s)

UAAC-AAUC (University Art Association of Canada | Association d'art des universités du Canada)

ISSN

0315-9906 (imprimé)

1981-4778 (numérique)

Découvrir la revue

Citer cet article

Boone, M. E. (2013). "A renewal of the fraternal relations that shared blood and history demand": Latin American Painting, Spanish Exhibitions, and Public Display at the 1910 Independence Celebrations in Argentina, Chile, and Mexico. RACAR : Revue d'art canadienne / Canadian Art Review, 38(2), 90-108.

https://doi.org/10.7202/1020796ar
Résumé de l'article

Les célébrations commémorant les indépendances nationales invitent les organisateurs et visiteurs à réfléchir sur les caractéristiques des cultures nationales et leurs rapports aux autres traditions culturelles. Les expositions d'art espagnol montées en 1910 à l'occasion de fêtes célébrant cent ans d'indépendance dans trois villes d'Amérique latine - Buenos Aires, Mexico et Santiago de Chile - ont offert à ces trois endroits culturellement et historiquement distincts l'occasion de réfléchir sur leurs rapports historiques et actuels avec l'Espagne. Cet article s'appuie sur des témoignages journalistiques, images populaires, correspondance diplomatique et oeuvres d'art provenant d'Argentine, du Mexique et du Chili pour examiner plusieurs questions relatives à l'Amérique latine. Que nous apprennent ces expositions sur l'art espagnol et latino-américain produit à cette époque ? Que nous disent-elles sur l'Argentine, le Mexique et le Chili et leurs rapports avec l'Espagne ? Comment la réception de l'art espagnol dans ces trois pays latino-américains peut-elle nous aider à comprendre les enjeux politiques et culturels de chaque nation ? En considérant la participation de l'Espagne à ces trois centenaires, nous examinons des questions qui touchent à la création des identités latino-américaines vis-à-vis de l’Europe et entre elles, ainsi qu'au riche domaine des études transnationales.
Tous droits réservés @ UAAC-AAUC (University Art Association of Canada | Association d'art des universités du Canada), 2013
Ce document est protégé par la loi sur le droit d'auteur. L’utilisation des services d'Érudit (y compris la reproduction) est assujettie à sa politique d'utilisation que vous pouvez consulter en ligne.

https://apropos.erudit.org/fr/usagers/politique-dutilisation/ 


\title{
"A renewal of the fraternal relations that shared blood and history demand": Latin American Painting, Spanish Exhibitions, and Public Display at the 1910 Independence Celebrations in Argentina, Chile, and Mexico'
}

\author{
M. Elizabeth Boone, University of Alberta
}

Résumé

Les célébrations commémorant les indépendances nationales invitent les organisateurs et visiteurs à réfléchir sur les caractéristiques des cultures nationales et leurs rapports aux autres traditions culturelles. Les expositions d'art espagnol montées en 1910 à l'occasion de fêtes célébrant cent ans d'indépendance dans trois villes d'Amérique latine - Buenos Aires, Mexico et Santiago de Chile — ont offert à ces trois endroits culturellement et historiquement distincts l'occasion de réfléchir sur leurs rapports historiques et actuels avec l'Espagne. Cet article s'appuie sur des témoignages journalistiques, images populaires, correspondance diplomatique et œuvres d'art provenant d'Argentine, du Mexique et du Chili pour examiner plusieurs questions relatives à l'Amérique latine. Que nous apprennent ces expositions sur l'art espagnol et latino-américain produit à cette époque? Que nous disent-elles sur l'Argentine, le Mexique et le Chili et leurs rapports avec l'Espagne ? Comment la réception de l'art espagnol dans ces trois pays latino-américains peut-elle nous aider à comprendre les enjeux politiques et culturels de chaque nation ? En considérant la participation de l'Espagne à ces trois centenaires, nous examinons des questions qui touchent à la création des identités latinoaméricaines vis-à-vis de l'Europe et entre elles, ainsi qu'au riche domaine des études transnationales.

W tenary of Mexican independence by supporting an exhibition of Spanish art, painter José Clemente Orozco loudly objected: "We protested to the Secretariat of Instruction: it was all very well to hold an Exposition of Spanish Art, but why did they give us, the Mexicans, nothing, when it was precisely our Independence that was being celebrated?"2 Mexico was not the only nation in Latin America to feature Spanish painting at its independence day festivities, for Argentina and Chile commemorated their liberation from colonial rule with exhibitions of Spanish art as well. The 1910 centenary celebrations_-modelled in many respects on the 1889 Exposition universelle in Paris, which likewise marked the centenary of a violent rebellion against authority-inspired a mix of admiration, surprise, and in some cases irritation on the part of artists and audiences in each of these Latin American nations.

This essay explores these Spanish centenary exhibitions in the context of the varying historical and contemporary specificities of Argentina, Chile, and Mexico. Using a wide range of primary material from newspapers, periodicals, and archives in each of these nations, it reconstructs the histories of these three exhibitions-from conceptualization to reception-and places them in the context of other forms of public display related to Spain, such as civic sculpture, political cartoons, and popular parades during the centenary year. It also considers early twentieth-century Latin American painting, offering transnational ways of thinking about and understanding artistic production in the countries under review. The multiple individuals involved in these various cultural manifestations form a "honeycomb" of differing connections to the Span- ish peninsula; ${ }^{3}$ some were born and lived in Spain, others were born in Spain and emigrated to Latin America, while others still were born in Latin America and studied in or otherwise identified strongly with Spain. What do these exhibitions say about Argentina, Mexico, Chile, and their multiple, complex relations with Spain? How can we study these transnational encounters, relationships in this instance between a colonial power and its former colonies, without reinstating the hierarchies of colonization? And how might this history aid our understanding of developing national identities and modern art in these three Latin American republics? The 1889 Exposition universelle provides a foundation from which to begin exploring these questions.

\section{Paris}

When the government of France decided to host a world's fair in 1889, most European monarchies, including Spain, refused to participate in an event that celebrated an insurrection resulting in the execution of a king. The Latin American republics, which like France had rejected monarchism, saw in contrast an opportunity to move centre stage. Several used public money for the creation of impressive national pavilions, prominently sited at the base of the Eiffel Tower: the Argentines commissioned the largest of these buildings, the Pabellón Argentino, loosely modelled on London's Crystal Palace; the Chileans erected a smaller, but equally elegant, domed edifice likewise of iron and glass; and the Mexicans built a distinctive Aztec-inspired palace. For each of these nations, the challenge was to construct a building that negotiated the ever-shifting and ultimately unstable binaries of American and European, Indigenous and Hispanic, traditional and modern. The manner in which they did this varied considerably based on the political, cultural, and economic 
history of each country, and scholars-Mauricio Tenorio-Trillo, Álvaro Fernández Bravo, and Carmen Norambuena Carrasco among them-have considered these issues for each of the three Latin American countries concerned. ${ }^{4}$ While Chile and Argentina chose French architects for the design of their buildings in Paris, Mexico chose native sons. And while Argentina and Chile (the first more successfully than the second) presented themselves in Paris in a bid to attract European immigration to populate their relatively empty lands, Mexico focused its efforts on the importation of foreign investment, the better to make use of its large Indigenous population.

Fair organizers in Paris developed an elaborate system of display that allowed each nation to exhibit material-from the fine and applied arts, manufactured goods, and machinery to food, agriculture, and horticulture-that suggested greater or lesser degrees of industrial development. In the grand international marketplace of Europe, each country promoted and differentiated itself by exhibiting its most well-known and readily commoditized merchandise. Whereas France and the United States showed off technology and mechanical products-France with Gustave Eiffel's Tower and the United States with the inventions of Thomas Edison-the Latin American republics showcased their natural resources: Chile its guano and nitrate, Argentina its beef, and Mexico its henequen, mineral wealth, and large workforce. Jostling between Latin American nations occasionally got ugly, as when the Chileans promoted themselves as a piece of Europe in Latin America, contrasting themselves to the Mexicans thus: "although we are only two million people, we represent a population almost as large as Mexico's, with its six million Indians, who are essentially useless and consequently more likely to combat civilization than accept it."5 Between the French centenary of 1889 and the Latin American anniversaries of 1910, such offensively prejudiced attitudes remained largely in place.

\section{Buenos Aires}

While the 1889 Paris centenary celebration occurred in a single geographical location during a specific moment in time, the Latin American centenaries were spread across the hemisphere over more than a decade. Argentina, Chile, and Mexico chose to celebrate in 1910.6 In addition to organizing ephemeral events such as parades and exhibitions, many Latin American nations tied their celebrations to city beautification and infrastructure improvement-the construction of new museums and the installation of better transportation and water systems, for example. Events and monuments were designed to create nation-specific histories that would resonate with and bind together diverse populations that, depending on the country, included new immigrants from Europe (Argentina and Chile)

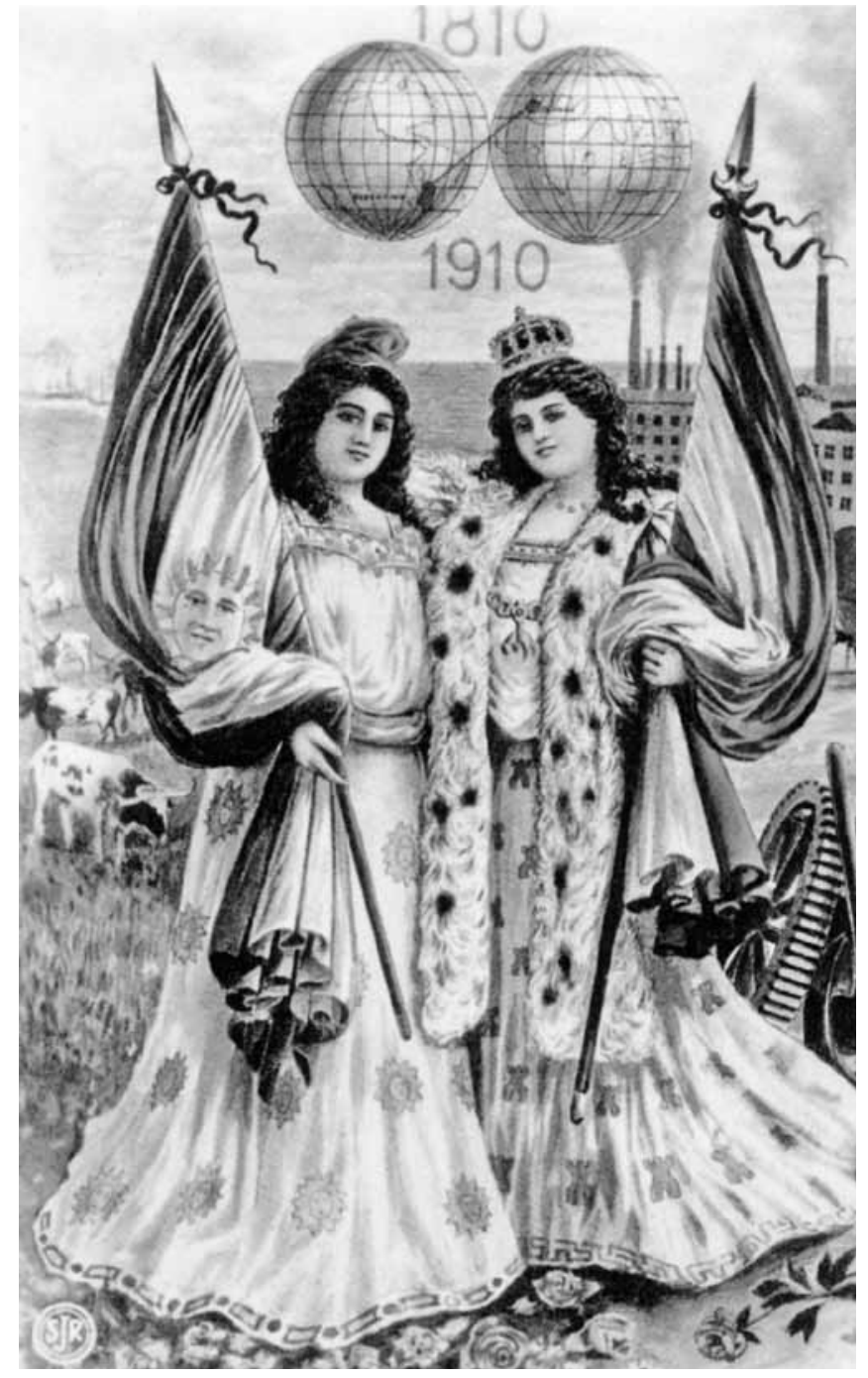

Figure I. El reencuentro de Argentina y España, ca. 1910. Colección CEDODAL (Photo: CEDODAL).

or large Indigenous and mixed-race communities (Mexico) that were living and working in regions constituted only during the course of the nineteenth century as independent, sovereign nations. The creation of national borders was a messy process, and wars had erupted as countries jockeyed for natural resources and to position themselves strategically for future development. Chile, for example, annexed mineral-rich regions of Peru and Bolivia in 1879 during the War of the Pacific, agreeing during the same conflict to cede most of Patagonia to Argentina in return for neutrality.

Newspapers and magazines covered the 1910 centenaries extensively, and rivalries continued as each country strove to show itself off to the world. Invitations were sent to 


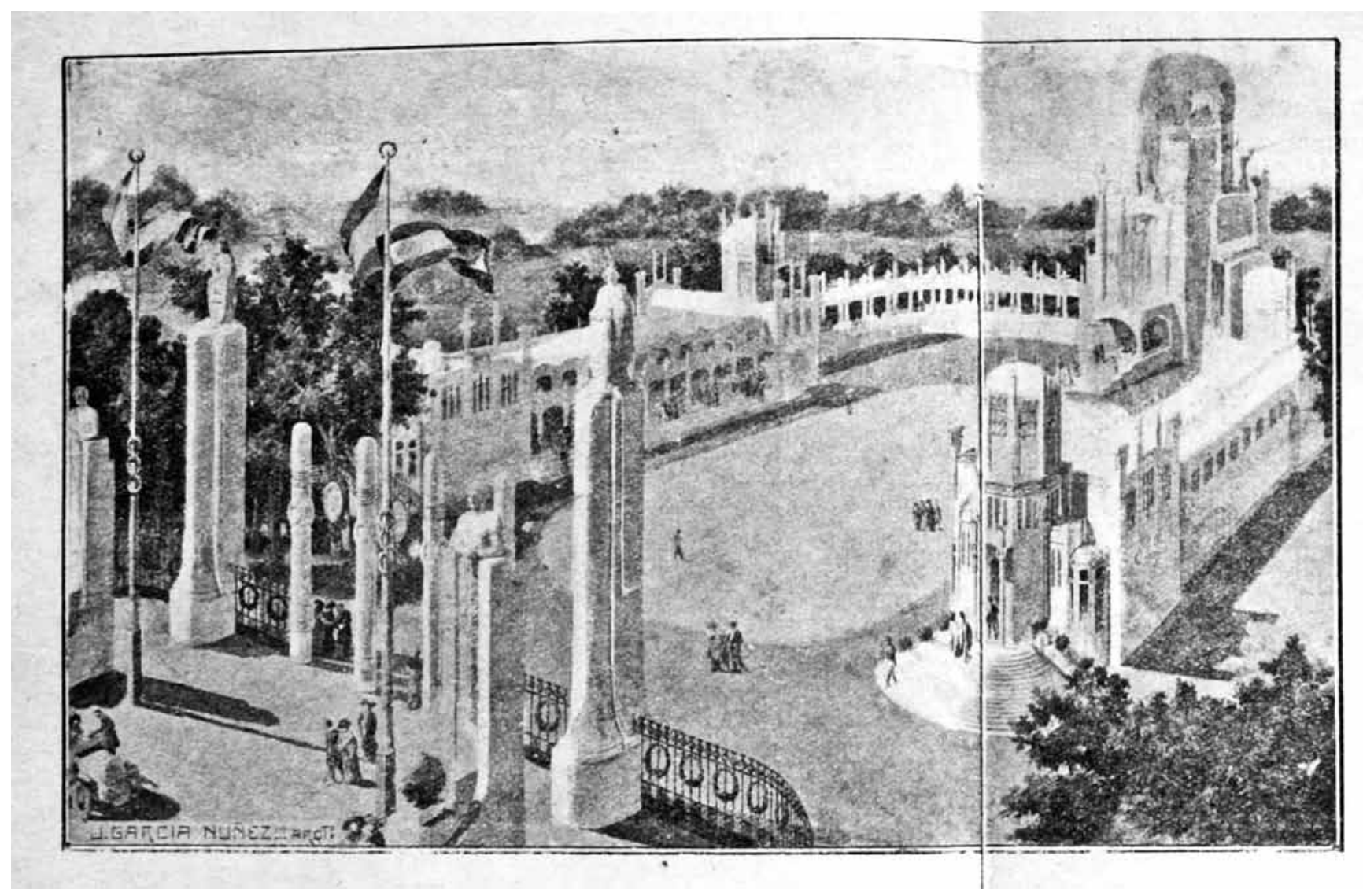

Figure 2. Pabellones Españoles, in Francisco Camba y Juan Más y Pi, Los españoles en el Centenario Argentino. Buenos Aires: Mestres, 1910, 88-89 (Photo: author).

governments abroad, and the importance of the officials sent to attend opening ceremonies became a marker of the political and economic consequence of each host country. The Spanish government responded to Argentina's invitation by sending the infanta Isabel, aunt of King Alfonso XIII, to Buenos Aires. Argentina was at this time a wealthy nation, attracting a large number of immigrants from Europe, many of them from Spain. The Argentine people, notes Rodrigo Gutiérrez Viñuales, a specialist in Spanish Argentine artistic relations, were responding to this influx of new immigrants from the Peninsula by replacing earlier rejections of Spanish colonialism with a broadly defined, generalized identification. ${ }^{7}$

The celebrations in Argentina were timed to begin on 25 May to mark the anniversary of the deposition of the Spanish viceroy in 1810 and to highlight events of 9 July 1816, when independence was formally declared. Activities and exhibitions continued to open throughout the rest of the year. More than any other centenary in Latin America, the Argentine celebration came closest to the European model of a world's fair, including large exhibitions devoted to agriculture, industry, transportation, hygiene, and the fine arts. Postcards and souvenirs depicted the renewed love of Argentina, with liberty cap on the left, and Spain, with Bourbon crown on the right (fig. 1). Argentina stands before an agricultural landscape populated by cattle and ships, the transportation mode by which Argentine meat was being shipped across the Atlantic, while the industrialization of Europe, suggested by machine parts and factories, lies behind Spain. Reconciliation with its former colonial master demonstrated the republic's physical and cultural maturity. Rather than appearing as mother Spain and daughter Argentina, the two countries are sisters. A single horizon places Spain and Argentina within the same, albeit differentiated, landscape, and the women —of similar size, age, and skin tone-share the space equally. This vision of Argentine ethnicity, like that promoted by nineteenth-century Argentine president Domingo Faustino Sarmiento, aligned the country with European, not Indigenous, ideals. Argentina's "Conquest of the Desert," spanning the 1870 s and early 1880 s, had brutally exterminated most 
Indigenous communities in Patagonia some thirty years earlier. ${ }^{8}$ Members of Argentina's Spanish colonia — residents of Buenos Aires who were born on the Peninsula and still identified strongly with Spain - were determined to sponsor an impressive public display on this important occasion, erecting a large civic sculpture as a gift to the city. ${ }^{9}$ Catalan sculptor Agustín Querol produced maquettes for the 25 -foot marble and bronze monument, which featured the allegorical figure of Argentina standing atop an elaborately ornamented base. ${ }^{10}$ The project was delayed repeatedly, however, first when Querol died in 1909, at which time sculptor Cipriano Folgueras took over the monument, again when Folgueras passed away two years later, and a third time when a large number of sculptures destined for the monument and shipped from Spain were lost at sea in 1916. The work was not inaugurated until 1927.

The Pabellones Españoles (fig. 2) were an even more ambitious project mounted by the Spanish colonia. Julián García Núnez, an Argentine-born architect schooled in Barcelona, was commissioned to design the temporary structure. This flamboyant complex included two symmetrical wings in which organizers installed food and industrial products, on the left and right respectively. Books, furniture, and a few artworks were displayed in the central pavilion at the back, and privately funded kiosques (not included in García's architectural rendering) offered consumables like cider and mineral water in the inner courtyard. A pamphlet distributed among businessmen on the Peninsula encouraged them to send their products to Buenos Aires, "in order to become great and strong again, not in terms of territorial expansion or military power, but in terms of industry and commerce."11 Most Spanish immigrants seeking economic opportunities in Argentina arrived from the northern provinces of the Peninsula, and the stylistic choice of Catalan modernisme recalls this industrialized region of Spain. Modernisme also expressed, according to architectural historian Ramón Gutiérrez, a desire to project a modern and dynamic image in the years following the losses of the Spanish-Cuban-American war of 1898.12

Vendors in Spain, as well as Spanish residents in Buenos Aires, were indeed eager to sell their merchandise to Argentina's prosperous population. Organizers requested a building subvention from the Spanish government, and while the government procrastinated, wealthy members of the colonia-chief among them José Artal, Tarragona-born president of the Spanish Chamber of Commerce in Buenos Aires - underwrote the construction, fully expecting to be reimbursed. The pavilions opened on 29 October, and most of the money never arrived. Spain's economic situation during the first decade of the twentieth century was precarious, and politicians in Madrid had more urgent problems to address-long-simmering conflict in North Africa, anarchist worker strikes in Catalonia, and widespread anger over military inscription policies - than an industrial fair on the other side of the Atlantic. The Chamber of Commerce, threatened in Buenos Aires by lawsuits and demands for payment, was still sending pleas for repayment seven years later. ${ }^{13}$

In addition to supporting the Pabellones Españoles, José Artal played a key role in the organization of Spain's display of fine arts. The Exposición Internacional de Arte del Centenario, accompanied by an illustrated catalogue, opened on 11 July. ${ }^{14}$ Everything was for sale, and a complete list of works sold was published shortly after the exhibition's close. ${ }^{15}$ In addition to work from Spain, this international exhibition included a display of Argentine artwork, along with paintings and sculptures from Western European and Scandinavian nations, the United States, Chile, and Brazil. The inclusion of paintings from Latin America in the fine arts exhibition hall was a significant gesture, for when Argentina, Mexico, and Chile had displayed paintings at the 1889 Paris fair, these had been relegated to secondary spaces and national pavilions. ${ }^{16}$ The structure of the 1910 Argentine pavilion rendered explicit the connection between the Paris World Fair and their own centenary celebration, as it literally embraced the reconstructed Pabellón Argentino built for the 1889 exposition (fig. 3). ${ }^{17}$

Visitors entered through the Argentine section, which consisted of three large galleries, before turning left to view works from Chile and the United States. These were the American nations with which Argentina wished to align itself most closely: Chile for its geographical proximity and predominantly European ethnic composition, and the United States for its high degree of industrialization. Plans for exhibition galleries function like maps, creating ideal geographies for the nation. ${ }^{18}$ In this instance, the European countries, on the other side of the Atlantic, along with Brazil, with its large population of African descent, were all to the side.

The Spanish display in Argentina, forming the crux of this case study, included over 250 works, with Ignacio Zuloaga, a Basque painter associated with the group known as the Generation of '98, filling a room of his own. ${ }^{19}$ The Generation of '98 brought together novelists, poets, and philosophers active at the time of Spain's war with the United States over Cuba in 1898. More broadly, the expression describes the moral, political, and economic crisis the followed Spain's loss of its colonies in Cuba, Puerto Rico, and the Philippines. ${ }^{20}$ Zuloaga was recognized with one of the three medals of honour awarded to Spain, and the Argentine government purchased one of his paintings at the close of the exhibition. Art dealers in Buenos Aires had a well-developed relationship with artists on the Peninsula, and Artal, who had been importing Spanish paintings to Argentina since 1897 , was only one of several individuals involved in the trade. ${ }^{21}$ But the quality of work being sent to Latin America was of concern to Argentine collectors, who complained that the 


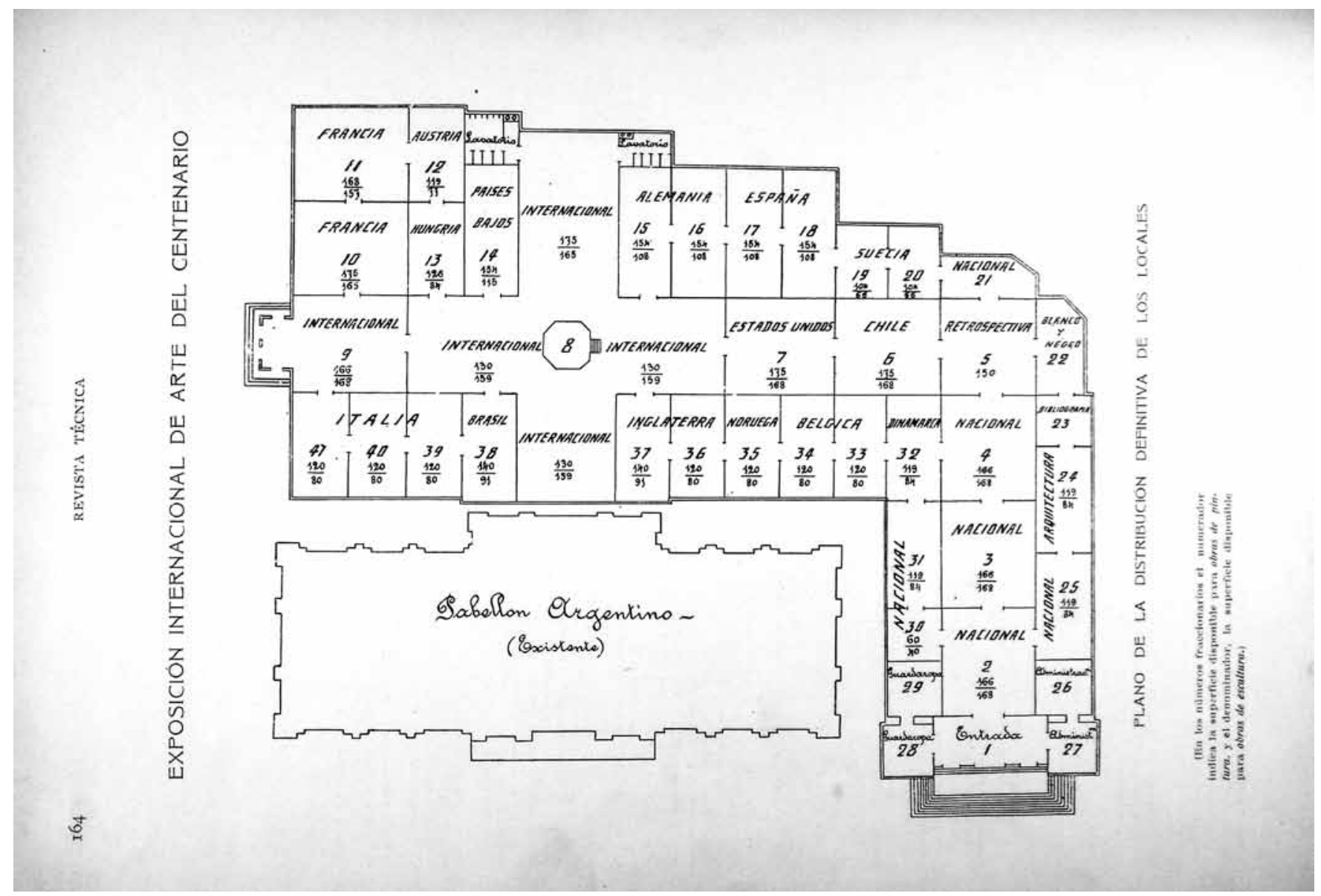

Figure 3. Plano de la Distribución Definitiva de los Locales, Revista Técnica, Suplemento de Arquitectura 8-9, 57 (1909): I64 (Photo: Rovere and Sandller).

Europeans were sending only those works that failed to sell in Paris or the United States. Artal apparently approached Zuloaga about sending his paintings to the centenary after arguing with Joaquín Sorolla, Spain's most successful painter at this time, about just this issue. ${ }^{22}$ When Sorolla refused to send anything at all, Zuloaga filled the gap. ${ }^{23}$

Struggling to define and reassess the Spanish nation in the aftermath of the "disaster of 1898," artists like Zuloaga abandoned the painting of modern French life and turned to subjects of traditional Spanish costumbres (customs). At the same time, Argentine viewers were buying Spanish paintings. ${ }^{24}$ While regional nationalisms became less important when Spanish immigrants left their country for another land, they did retain some relevance; paintings of Castile, in addition to depictions of Asturias, the Basque Country, Catalonia, and Valencia, were especially popular with new residents of Argentina seeking to retain links to their homeland. Andalusia, a region from which few immigrants hailed, and which non-Spanish tourists frequently conflated with the entire country, was less so. ${ }^{25}$ After the war of 1898, moreover, Latin American countries began to see Spain and its offer of hispanismo as less threatening than the expansionist policy of pan-American unity promoted by the United States. Uruguayan literary critic José Enrique Rodós rejection of the United States, personified by the figure of Caliban in his famous essay Ariel from 1900, emerged from this same political and cultural climate.

Zuloaga was not the only artist to benefit from Sorolla's absence. Catalan painter Hermenegildo Anglada-Camarasa also sent a large, if controversial, display of work to Buenos Aires. Argentine critic Augusto Gozalbo claimed in Athinae, an Argentine periodical devoted to the fine arts, that because the Spanish jury refused to include Anglada's work as part of their display, it was shown in the International rather than Spanish section of the exhibition. ${ }^{26}$ Some critics found his brilliant colour, expressive brushwork, and blatantly decorative approach to be shocking and strident. ${ }^{27}$ But like Zuloaga, Anglada had 


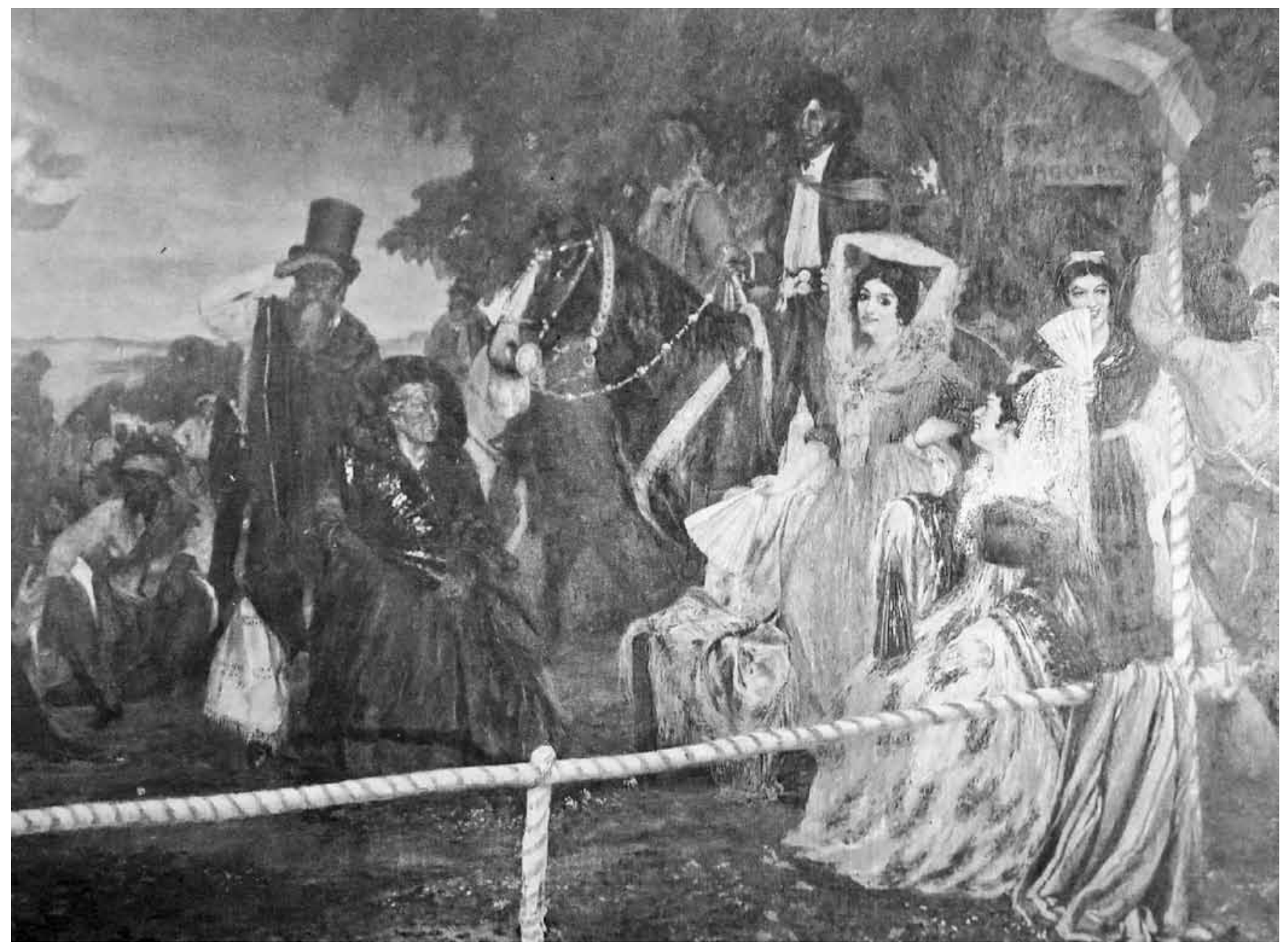

Figure 4. Cesáreo Bernaldo de Quirós, Carrera de sortijas en el día patrio, 1910. Oil on canvas, $290 \times 380 \mathrm{~cm}$. Patrimonio del Museo Provincial de Bellas Artes “Dr. Pedro E. Martínez," Paraná, Entre Ríos, Argentina (Photo: Gutiérrez Zaldívar).

recently shifted his subject matter from the representation of stylish Parisians to the folk traditions of Valencia and Mallorca. He too received a medal of honour, and his studio became a magnet for Latin American painters travelling to Europe after the centenary. ${ }^{28}$ Argentine painters, like artists in Spain during the early twentieth century, were engaged in a heated debate about nationalism and art, and Anglada's fusion of a modern style with national subjects resonated strongly with young Argentine painters such as Cesáreo Bernaldo de Quirós, who also won a medal of honour at the centenary exhibition.

Quirós, born in the Argentine province of Entre Ríos to a Basque father and Portuguese mother, had studied painting in Buenos Aires before moving to Europe in $1900 .{ }^{29} \mathrm{He}$ was introduced to Anglada's work during a sojourn in Mallorca in 1905. Returning to Buenos Aires, he worked with colleagues to organ- ize exhibitions of Argentine art in the years preceding the centenary. Carrera de sortijas en el día patrio (fig. 4), a large canvas painted with fluid brushwork in a modern high-keyed palette, depicts spectators watching a traditional gaucho pastime not found in Spain, the carrera de sortijas, or the race for the ring, a contest in which men on horseback gallop at breakneck speeds toward a horizontal pole from which is hung a small ring (the sortija). The rider who successfully grabs the ring is the winner of the competition, and he may present his prize to the woman of his choice. This particular race, according to the title of the work, occurs on a dia patrio, a national holiday, and we can see the Argentine flag waving gaily at the top right. "Let a national art find inspiration in our surroundings," advised Argentine critic Carlos Giambiagi in an essay from 1910. "Paint the customs of today, the representatives of the immigrant people who 
are differentiating and adapting themselves to become in the future what will be the great American race." 30 By portraying a traditional Argentine subject in a modern European style, Quirós subverted the colonial binary of old world and new, inverted tradition and modernity, synthesized Europe and the Americas, and created a modern American painting.

\section{Santiago de Chile}

Chile's celebration, scheduled later in the year to coincide with the anniversary of the meeting of its first independent junta on 18 September 1810, was much less elaborate than Argentina's. It was almost cancelled, for President Pedro Montt left for medical treatment shortly before the inauguration of festivities and died unexpectedly in Germany. To make matters worse, Vice President Elías Fernández fell sick and died two weeks later, leaving the country twelve days from the opening ceremonies without an elected leader. Minister of Justice and Pub-

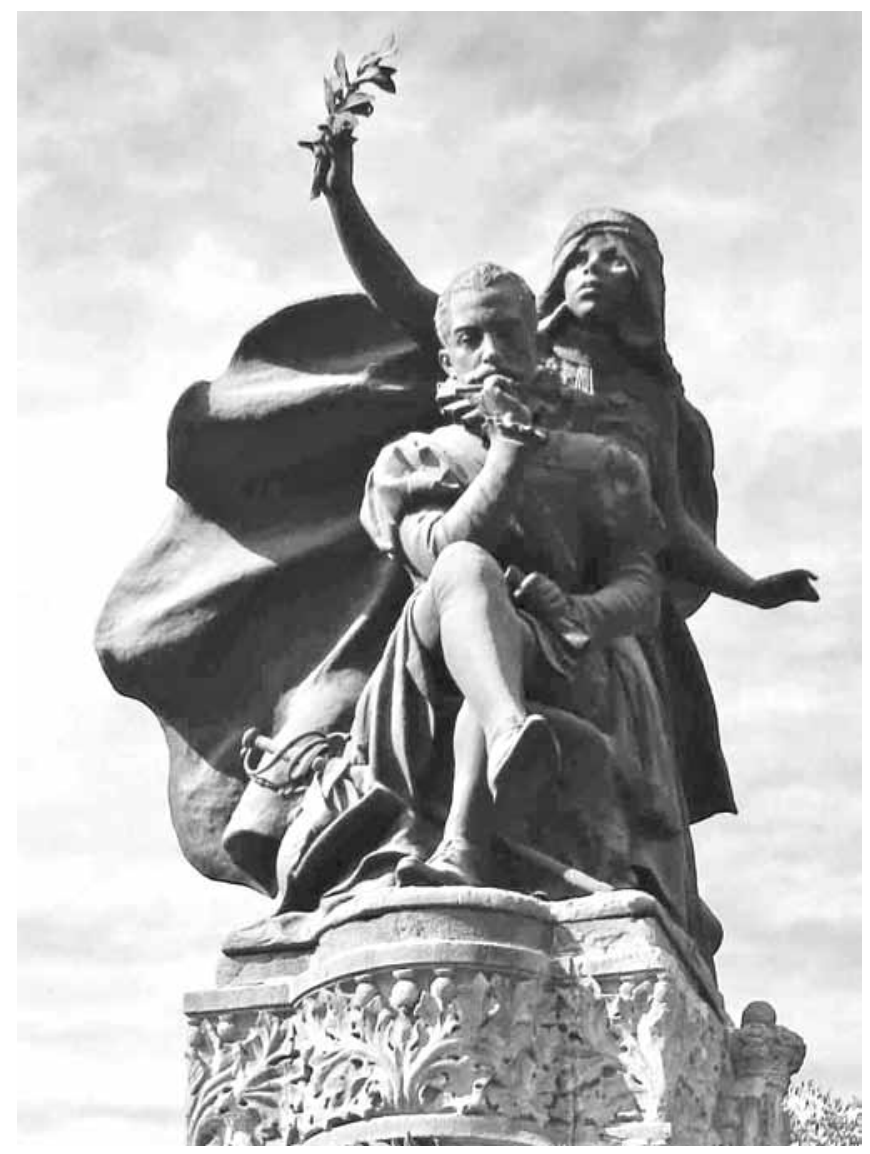

Figure 5. Alonso Coll y Pi, Estatua de Don Alonso Ercilla, 1910. Gift of the colonia española to the city of Santiago de Chile (Photo: author). lic Education Emiliano Figueroa stepped in as master of ceremonies, while the Chilean elite put forward a new president, ostensibly providing the world with a fine example of smooth democratic process. But the rapidity and unanimity with which this election occurred (Ramón Barros Luco was elected with a 98\% majority) obscured a growing fissure between the country's oligarchy and the large number of poor Chileans struggling to make ends meet. Historian Macarena Ibarra indicates that Santiago was a divided city in 1910 , with part of the population living in modern splendour and the other part in misery. Social critics used the centenary to point out that independence in Chile had benefited the wealthy, but not the workers. ${ }^{31}$ The only head of state to attend Chile's opening ceremonies was Argentine president José Figueroa Alcorta. Spain sent a career diplomat, José Brunetti Gayoso, the Duke of Arcos, to represent the king.

Festivities in Chile began on 12 September and continued through the end of the month. Popular magazines such as Zig-Zag published special issues, and the government sponsored military parades, automobile races, and a plenary session of the National Congress. Rodó, who continued to be troubled by US interference in Latin American affairs, spoke at this last event. Reacting to the territorial wars that had marked post-Independence Latin American history, Rodó delivered one of his most compelling calls for a unified Latin America: "In addition to celebrating the centenary of Chile, Argentina, and Mexico," he proclaimed, "I feel and acknowledge the centenary of Spanish America. In spirit as well as in history, there is only one true Hispanic American centenary; because in spirit and in history, there is only one Hispanic American revolution."32

Relations between Spain and Chile had been damaged in 1866 when Spain bombed Valparaiso, but had gradually improved in the later nineteenth century. This was a period of tremendous economic growth for Chile, as territorial gains made during the 1879 War of the Pacific provided rich deposits of potassium nitrate, a mineral used to make both fertilizer and gunpowder. But Chile, surrounded by water, mountains, and desert, was still not well connected to Europe or the rest of the Americas. The trip from Europe to Chile took forty days, whereas the trip to Argentina could be made less expensively in twenty-five. Chile's population grew from 1,083,800 in 1843 to $3,249,297$ in 1907 , but only $0.5 \%$ of all European immigration to the Americas went to Chile, while $46 \%$ went to Argentina and $3 \%$ to Mexico. 33

As in Argentina, several of the foreign colonias commissioned civic sculptures to beautify the city of Santiago during the centenary year: the Germans erected a fountain shaped like the prow of a boat, the French a Monument to Liberty, and the Spanish a sculpture dedicated to sixteenth-century soldier and poet Alonso de Ercilla (fig. 5). Ercilla had fought 
BOONE | "A renewal of the fraternal relations that shared blood and history demand"

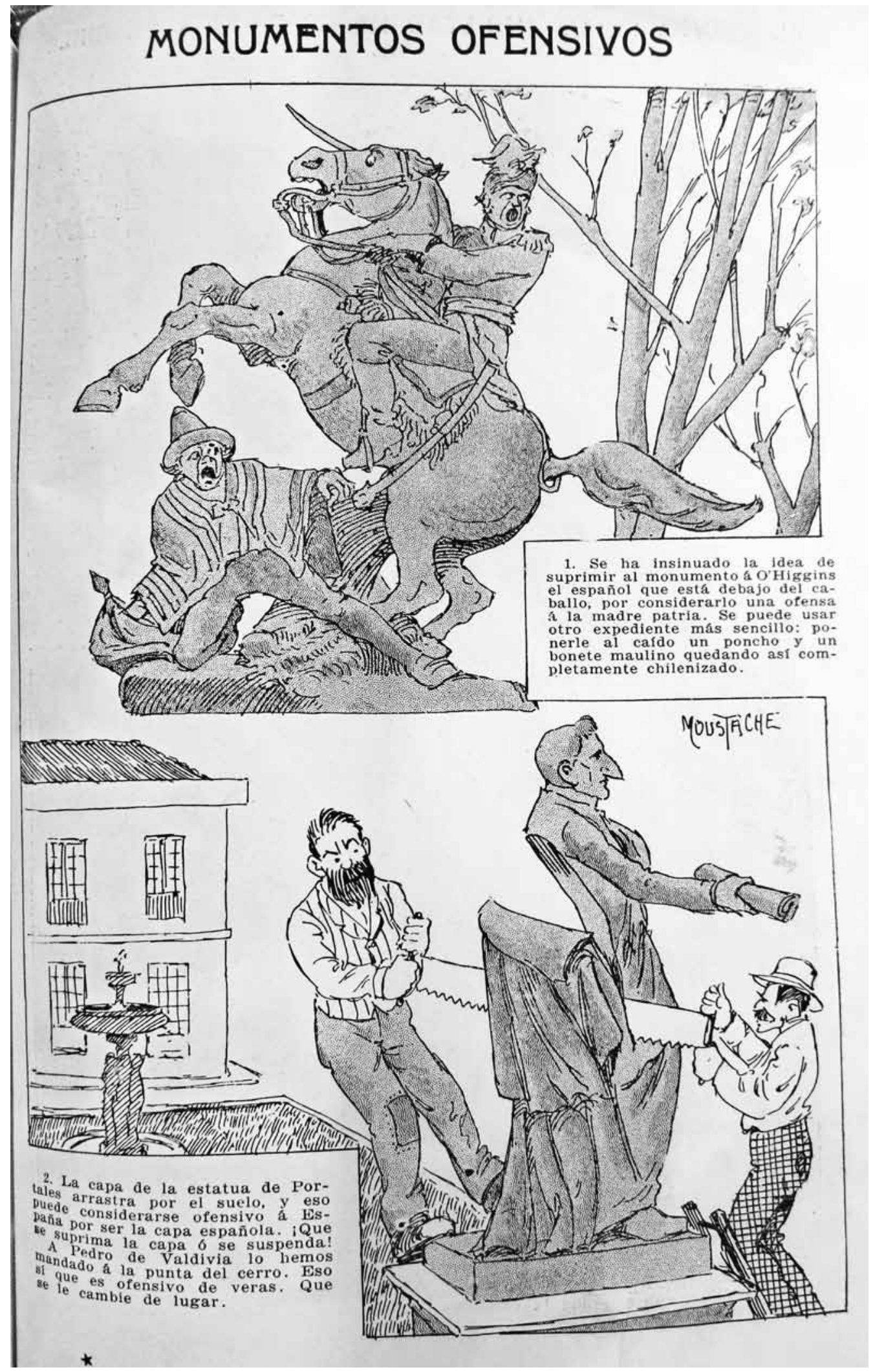

Figure 6. Moustache, "Monumentos ofensivos," Zig-Zag 6, 279 (25 June 1910), unpaginated (Photo: author). 
for Spain against the native people in Chile and composed an important Chilean national epic, La Araucana. ${ }^{34}$ The 1910 centenary monument, designed by Catalan sculptor Antonio Coll y $\mathrm{Pi}$, who had arrived in Santiago four years earlier, was well received when unveiled at a morning ceremony on 19 September. Ercilla and his muse are racially differentiated-Ercilla has a wide brow, aquiline nose, and elegantly styled beard and moustache, while his companion is depicted with a broad nose, wide-set eyes, and full lips. Thus gendered as female, the Indigenous Araucanian inspiring the European conquistador poses no threat to state-promoted Eurocentric Chilean identity.

Concerns during the centenary about the reception of sculpture erected earlier in Santiago appeared often in the popular press. Zig-Zag, for example, published a cartoon in June 1910 depicting the equestrian monument of Chilean independence fighter Bernardo O'Higgins (fig. 6). The original bronze, designed in 1872 by French sculptor Albert CarrierBelleuse shortly after Spain's attack on Valparaiso, includes a hapless Spanish soldier trampled beneath the feet of O'Higgins's rearing mount. The text of the Zig-Zag cartoon seeks to soften such anti-Spanish messaging and reads as follows: "It has been suggested that the Spaniard beneath O'Higgins's horse should be removed in order to avoid offending the Mother Country. But here is an easier solution: simply cover the fallen soldier with a traditional poncho and cap to turn him into an ordinary Chilean." 35 A tongue-in-cheek suggestion, the change of clothing may have taken care of the Spanish problem. But it also conveyed a second, less humorous Chilean reality, for in 1910 it was the ordinary Chilean, according to social reformers, who was being trampled beneath the feet of the Chilean elite. Unrest in Chile-from meat strikes to work stoppages—-had already led to several violent confrontations in the years leading up to the centenary. The lower portion of the cartoon, below O'Higgins, offered a solution for a second problematic sculpture that had been erected earlier in the city; in this case, suggested the cartoonist, the Spanish-style cloak dragging unceremoniously on the ground behind conservative Chilean statesman Diego Portales should simply be sawn off.

Cultural sensitivities were also at play in Chile's Exposición Internacional de Bellas Artes, which opened with an illustrated catalogue on 17 September in the newly completed Palacio de Bellas Artes, a Beaux-Arts structure designed by French-trained Chilean Emilio Jéquier. ${ }^{36}$ Dividing the building into sections, the organizing committee placed the Chilean display on the second floor in the centre, surrounded by France-the country to which wealthy Chileans usually looked for cultural inspiration-Argentina, and Brazil (fig. 7). The Spanish display, providing the focus for this case study, was divided between two galleries on the periphery and a third gallery below. Alberto Mackenna, commissioner general for the exhibition, credits
Francisco Álvarez de Sotomayor, a Spanish artist from Galicia hired in 1908 to serve as professor at the Academy of Fine Arts, for suggesting that Chile organize an international exhibition to celebrate its centenary year. ${ }^{37}$

According to art historian Pedro Zamorano Pérez, Sotomayor was frustrated by the privileging of French culture in Chile and used his new position to promote modern Spanish art as an alternative to "foreign" French styles. ${ }^{38} \mathrm{He}$ provided Mackenna with introductions to artist friends Manuel Benedito and Eduardo Chicharro, both of whom were placed on Spain's organizing committee, and encouraged his colleagues in Europe to fill the Spanish section with paintings that presented the diverse regions of Spain to the people of Chile. Sotomayor exhibited three elegant portraits in the Spanish section as well. These, along with four paintings by Benedito, four by Chicharro, two by Sorolla, and one by Zuloaga were among the 101 works gathered by Mackenna from the Peninsula.

Despite Sotomayor's efforts, Mackenna's trip to Spain was hampered by assumptions about Chile's lack of cultural consequence abroad. While Sotomayor's introduction guaranteed cooperation from Benedito and Chicharro, Sorolla refused to participate. Arriving at the studio, wrote Mackenna later, Sorolla received him coldly, saying he had nothing to send and that his public was in the United States, where he could earn fistfuls of money. "Sorolla dreamed only of dollars and looked with disdain at the feeble Chilean peso," recalled Mackenna in his memoirs of the trip. ${ }^{39} \mathrm{He}$ left in despair, for a painting by Sorolla, even a second rate work unworthy of the United States, would complete his Spanish exhibition. Novelist Vicente Blasco Ibáñez, like Sorolla from Valencia and determined to change his compatriot's mind, accompanied Mackenna on a second visit several days later. "Aren't you an ungrateful dog," remarked Blasco Ibáñez to Sorolla upon entering the studio. "Don't you remember that you bought your first frock coat with Chilean money? Don't you remember [Chilean collector] Sr Errázuriz, who once paid you a thousand duros for a group of paintings when you usually earned only a hundred pesetas?" He continued, "Of course you are going to send a few paintings to the exhibition in Chile," then climbed on a chair, removed two canvases from the wall, and handed them over to Mackenna. ${ }^{40}$

At the close of the exhibition, the Chilean government granted money for the purchase of art. Half of it was spent on works from France and Spain. ${ }^{41}$ Both Mackenna and Sotomayor were involved in the decisions, and neither Sorolla nor Zuloaga were on the final list. Due to the difficulty of pulling together an international jury of artists in Santiago, the commission gave all who participated in the exposition a commemorative medal. Only Chilean artists and foreign artists resident in Chile for more than ten years were eligible for the competition, and the prizes went to established rather than young up-and-coming artists. 42 


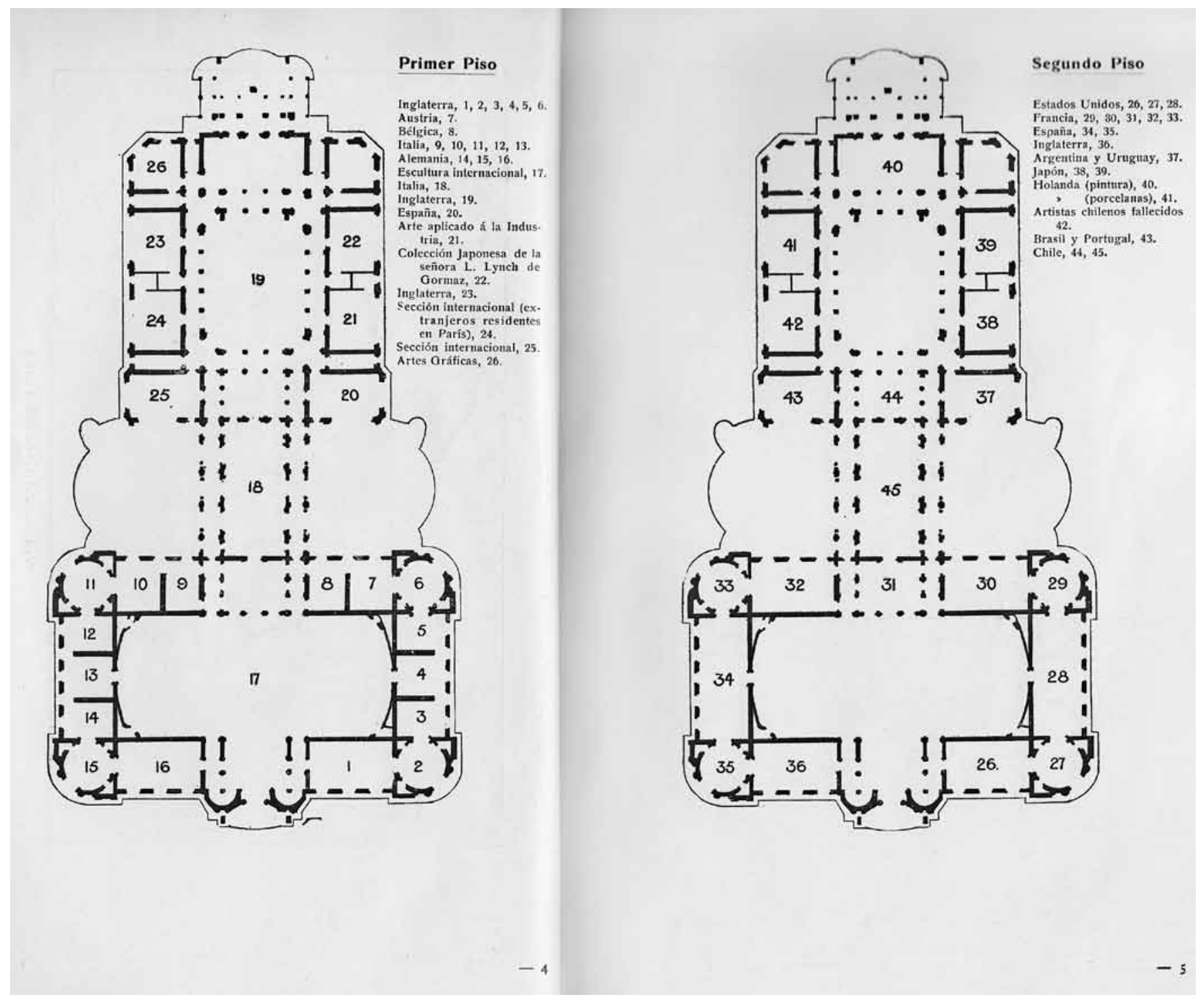

Figure 7. First and second floor plans, from the Catálogo oficial ilustrado; Exposición Internacional de Bellas Artes de 1910. Santiago de Chile: Imprenta Barcelona, 1910, 4-5 (Photo: author).

The Chileans, like the Argentines, were concerned about what they perceived as a lack of originality in their art and the need to develop their own national school. Ricardo Richon Brunet, French-born author of the centenary catalogue essay on the history of art in Chile, wrote that Chilean art began to develop with the 1843 arrival of French painter Raymond Monvoisin. The Academy of Fine Arts was founded to educate Chilean artists in the Neoclassical tradition several years later, in 1849. Pedro Lira, the first Chilean-born director, also studied in Paris, and students were invariably sent to France after beginning their training at home. Sotomayor argued that Chileans who wanted to develop their own national culture needed to stop looking toward France and begin acknowledging their Spanish heritage. Even Richon Brunet ended his essay on Chilean art with an acknowledgement of Spain's central position in relation to Chilean art:

How can Chile not have artistic instincts, a nation that springs in large part from the Spain of Velázquez, of $\mathrm{Mu}-$ rillo, of Goya, of Cervantes, and of Calderón, the magnificent trunk upon which have been grafted branches of all the people of Europe, the elegance and taste of the French, the gravity of the German, the classicism of the Italian, and the refinement of the English? 43 


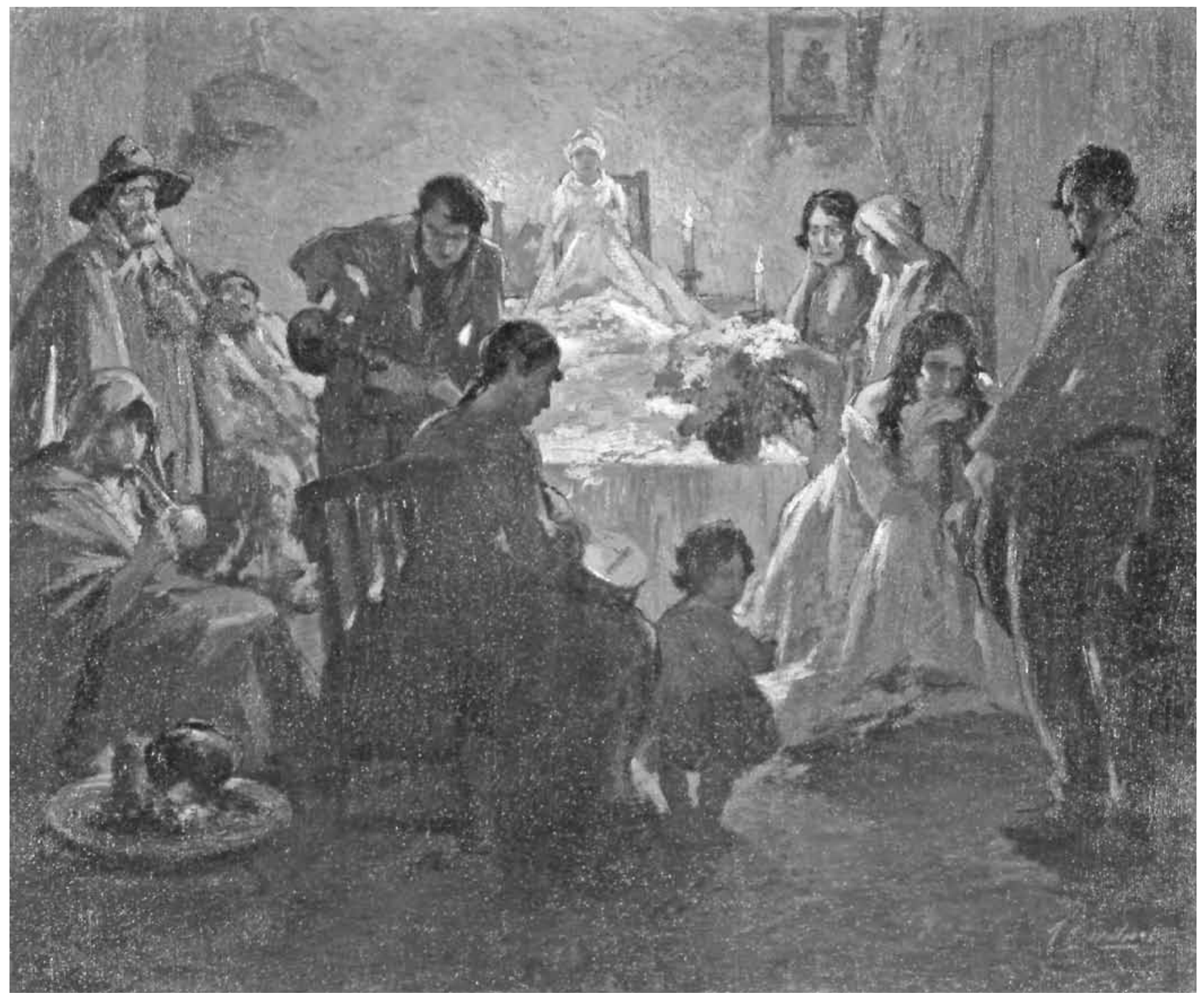

Figure 8. Arturo Gordon, El velorio del angelito, after 1910. Oil on canvas, $100 \times 120$ cm. Colección Pinacoteca Universidad de Concepción, Chile (Photo: Pinacoteca Universidad de Concepción).

Chileans claimed to be Europeans transplanted to Latin America, and Indigenous cultural production is notably absent from Richon Brunet's history of Chilean art. Young Chilean painters coming of age during the centenary, a group that studied with Sotomayor and became known as the generacion del centenario, painted traditional Chilean subjects in the cautiously modernist style of the Spanish paintings exhibited in 1910. 44 These artists, for instance Arturo Gordon, explored with rapid brushstrokes such Euro-Chilean (rather than overtly Indigenous) folk customs as the funerary wake for a young child (fig. 8). 45

\section{Mexico City}

Mexico's demographics in 1910 were significantly different from Argentina's or Chile's. This region had been the site of large urbanized Indigenous cultures during the pre-Hispanic period, and when parish priest Miguel Hidalgo called for independence from Spain at the end of the colonial era, the population of Mexico consisted of 2.5 million Indigenous inhabitants, 1.2 million mixed-race mestizos, 1 million European (primarily Spanish) Creoles, and 70,000 Spanish Europeans. ${ }^{46}$ Surnames from Italy, Germany, England, and France, frequently found in 


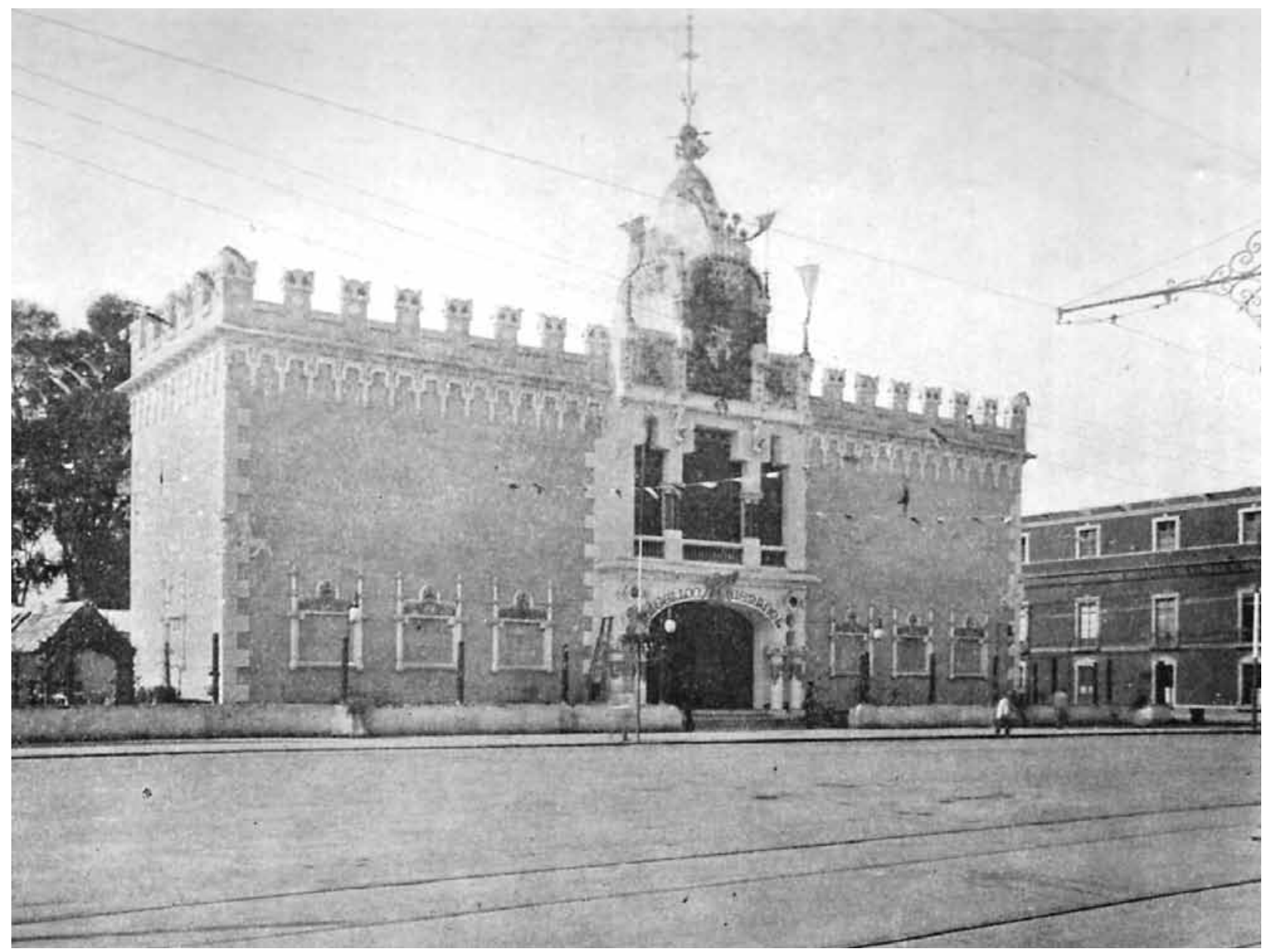

Figure 9. Edificio de la Exposición Española, in Genaro García, Crónica oficial de las fiestas del primer centenario de México. Mexico: Talleres del Museo Nacional, 191।, 242 (Photo: author).

Argentina and Chile, are uncommon in Mexico, and although immigration continued during the course of the nineteenth century, the ratio of Indigenous, mestizo, and Spanish Creole inhabitants remained roughly the same. After independence, power, influence, and wealth resided largely in the hands of the Creole elite.

Mexican president Porfirio Díaz, despite his birth as the mestizo son of a Creole father and Indigenous Mixtec mother, promoted European ideals and foreign investment in the country's infrastructure. ${ }^{47}$ Mexican elites looked to France when making plans for the 1910 centennial, and several had hoped for a world's fair similar to the 1889 Exposition universelle. 48 Centenary events were planned to coincide with the 16 September anniversary of Hidalgo's Grito de la Independencia (Cry of Independence). The grand historical parade held the day before epitomized the government's rationalist view of history, one that systematically moved from a primitive past toward the modern present. Divided into three sections, Conquest, the Viceroyalty, and Independence, the spectacle employed a cast of thousands marching down the Paseo de la Reforma to the centre of town. The route passed the Spanish pavilion, as well as several historical monuments, among them the Angel of Independence and the Benito Juárez Hemicycle, both of which were inaugurated during the centenary year. Earlier statues dedicated to Spanish monarch Carlos IV, Christopher Columbus, and Cuauhtémoc, the last Aztec emperor, also lined the route, and some 50,000 observers watched the procession. The final section of the parade-Independence-concluded not with Hidalgo's 1810 call to arms, but with Emperor Agustín de Iturbide's triumphant entry into the city in 1821, at the end of the wars of independence. The decision to feature Iturbide suggests both a reluctance to celebrate rebellion and a softening toward Spain. ${ }^{49}$ Peace, 
not revolution, was the Porfirian goal for the centenary of independence in 1910 .

Although the government of Porfirio Díaz sponsored parades, new public buildings, and a large number of parties, it did not include in its plans an international exhibition of art. As a result, a group of Spanish businessmen living in Mexico decided to step into the void. "Their love for our country," explained the newspaper El Imparcial, "has resulted in the creation of a Central Spanish Centenary Commission, charged with studying the best way for the Spanish residents of Mexico to celebrate the glorious date of our first hundred years of independence." 50 Justo Sierra, Mexico's Minister of Public Instruction and Fine Art, furthered the project by providing government land near the centre of the city and 35,000 Mexican pesos for the construction of a temporary edifice (fig. 9).51 Miguel Bertrán de Quintana, a Catalan architect in Mexico City to study its sani-

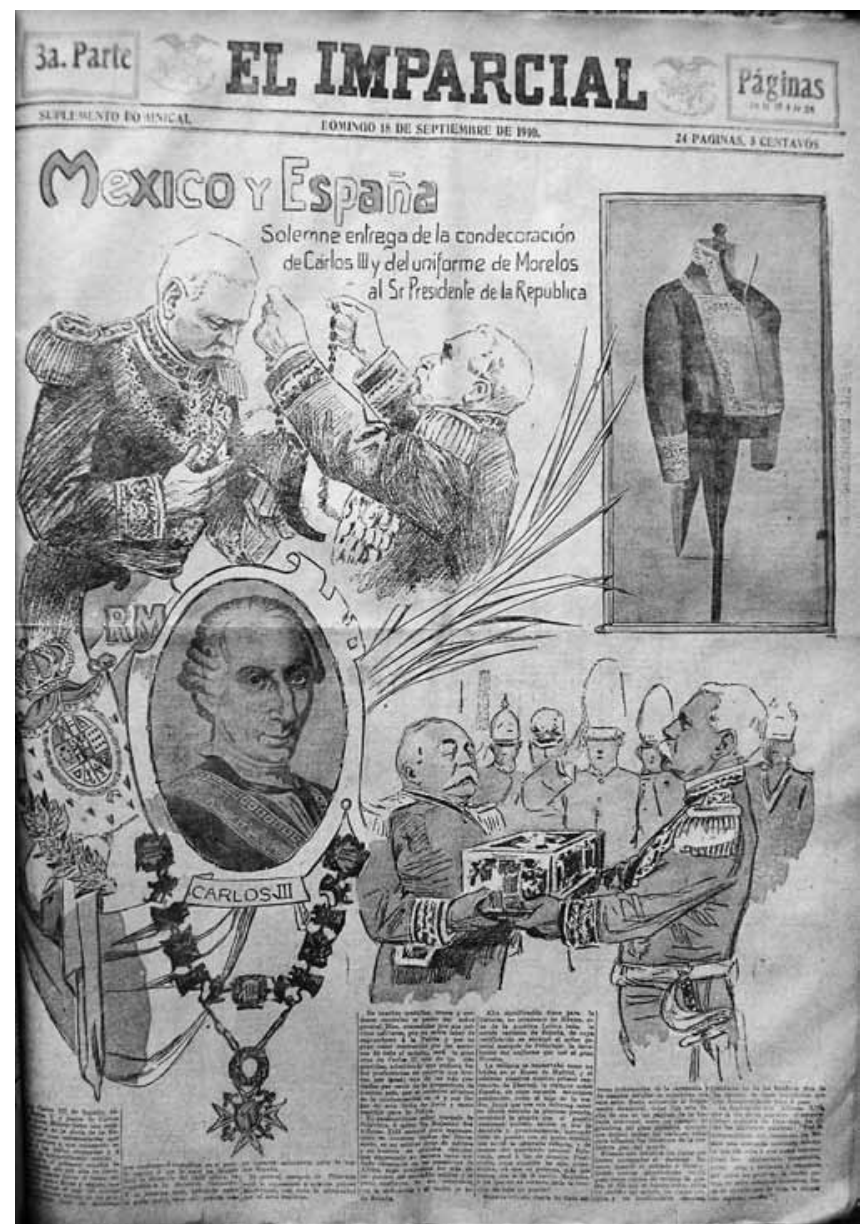

Figure I0. "México y España," El Imparcial, I8 September 19I0, Sunday Supplement, I (Photo: author). tation system, designed the neo-Gothic structure, which like the edifice in Buenos Aires, gestured through its historicism toward an earlier era of Catalan economic success. Bertrán also returned to the Peninsula to visit artist studios and convince its artists to send their work to Mexico. The Oriental Shipping Company of Japan, hoping to expand its own exports to Mexico, organized a concurrent exhibition of Japanese decorative arts to complement the exhibition from Spain. 52

La Exposición Española de Arte e Industrias Decorativas, the third exhibition of Spanish art examined in his essay, was open to the public for seven weeks, from 9 September until 1 November. It is difficult to reconstruct the exhibition in the absence of a catalogue, but installation photographs and newspaper reviews have allowed scholars to compile a provisional list of approximately 250 works, mostly paintings, but also sculptures and architectural renderings. 53 Decorative arts (ceramics, metalwork, and furniture) were displayed on the ground floor, and fine arts were above. Zuloaga sent at least three paintings, Benedito four, Chicharro three. And Sorolla, in a surprise gesture, sent eight.

Most of the paintings were available for purchase, but the Spanish exhibition in Mexico resulted in few sales, for unlike Buenos Aires, Mexico City did not have a system of galleries developing a market for painting nor a large immigrant population that identified with Spain. When Telésforo García, a spokesperson for the Spanish community in Mexico City, was asked about the exhibition's commercial failure, he hastened to explain:
We never proposed a utilitarian goal, a financial gain; but if we had harboured that objective, then I would have to say that the exhibition was a disaster. Why? Because of the public's lack of appreciation for beauty? No, of course not. What caused and will cause for many more years the finan- cial failure of great exhibitions of art in Mexico is simply the general level of poverty. 54

García's explanation, however, is contradicted by the huge number of sales seen by organizers of the Japanese decorative arts exhibition; 55 another factor may have been the growing dissatisfaction with Díaz and his government, popularly perceived as pro-Spanish. 56 Oblivious to the resentment simmering beneath the surface of public opinion, the government compensated for low sales by allocating an additional 20,700 pesos for the purchase of eight paintings for its national collection, among them, works by Beneditio, Chicharro, and Sorolla. 57

The complexity of Mexico's relationship to Spain during the centenary year is revealed in a comparison of three printed sources from 1910: El Imparcial, a large-circulation Mexican daily partially underwritten by the Porfirian government; El Correo Español, a more modest newspaper published by and for the Spanish colonia; and a broadsheet designed by popular Mexican 


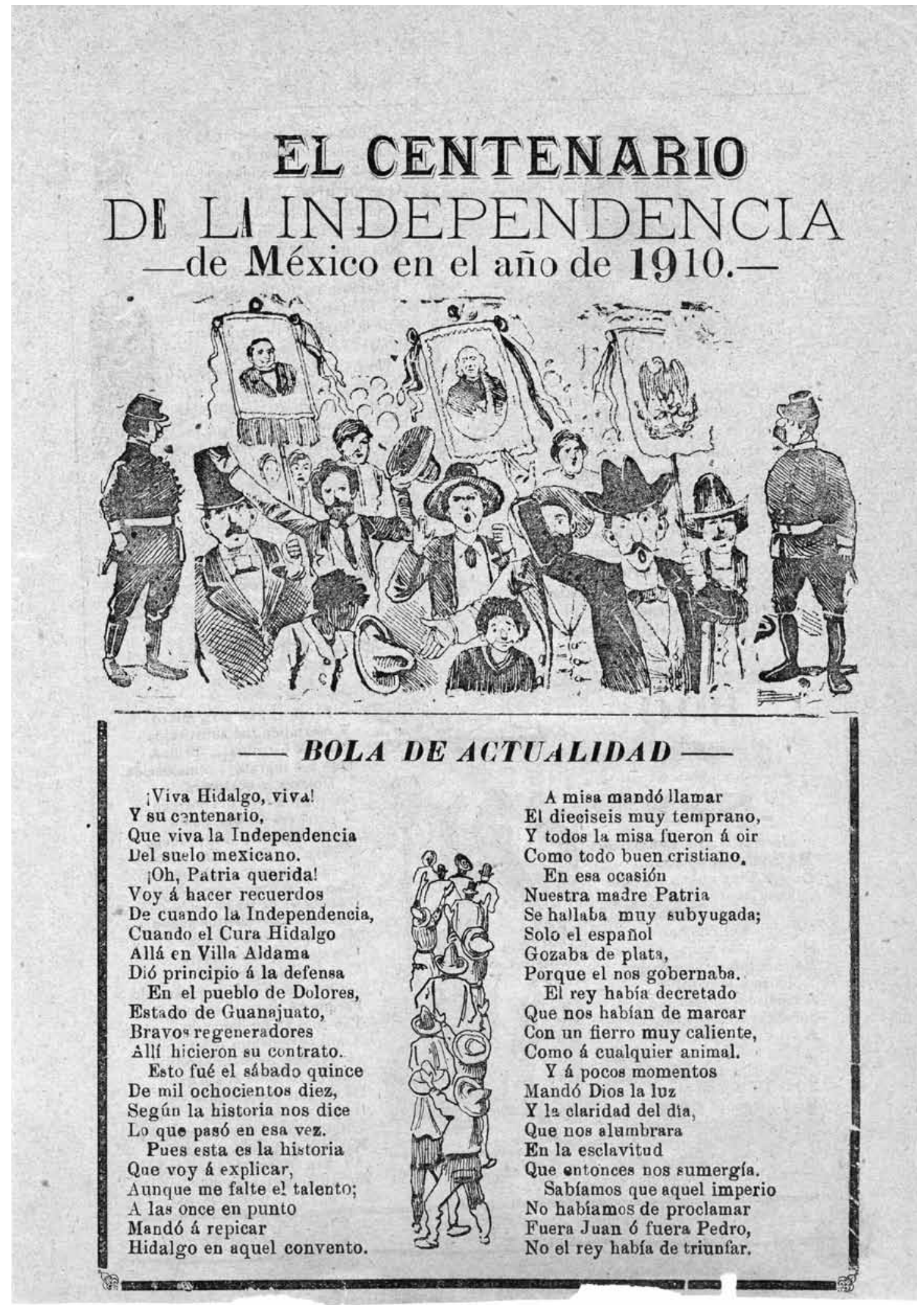

Figure II. José Guadalupe Posada, El Centenario de la Independencia de México en el año de 1910, 1910. Relief print, $28.3 \times 20 \mathrm{~cm}$ (sheet). DeGolyer Library, Southern Methodist University, Dallas, Texas, Broadside FI234.P687 1903 (Photo: DeGolyer Library). 
printmaker José Guadalupe Posada for mass circulation among the Mexican people. 58 The images in El Imparcial depict Spain's Marquis of Polavieja, an official of significantly less importance than the infanta Isabel, decorating General Díaz with the Medal of Carlos III (fig. 10). A portrait of the Bourbon king and an enlarged illustration of the medal are immediately below. On the right is a photograph of the uniform worn by Mexican independence fighter José de Morelos, a relic held by Spain since his execution in 1815, and an image of Polavieja handing a box containing the uniform to General Díaz. The illustrations depict Díaz quite a bit taller than Polavieja, with a robust head of white hair, and despite his eighty years, in much trimmer form. Díaz is portrayed with considerable dignity and on equal terms with—on a much higher visual plane, in fact, than-his Spanish counterpart.

El Correo Español, a small-circulation publication produced without illustrations for Mexico's Spanish community, defined this relationship somewhat differently. Noting that all colonies (like children) need to assert their independence at some point in their history, this newspaper claimed that

Spanish political domination ceased; but Spain remained latently alive in the soul of this new nation, in the customs, in the aspirations, in the ideals, and above all in the language in which it expresses its feelings and the spirit of its race. A century has passed; and one hundred years of evolution and progress have not only extinguished any of the lingering feelings of mistrust and prejudice that gave rise to the fight for independence, they have also allowed for a renewal of the fraternal relations that shared blood and history demand.59

Posada's broadsheet tells yet a third story (fig. 11).60 Depicting a centenary celebration that looks more like a quickly organized political demonstration than one of the carefully orchestrated parades sponsored by the Porfirian government, Posada's image shows diverse members of Mexican society waving placards of, from left to right, Benito Juárez, Miguel Hidalgo, and the Mexican eagle. Indeed, the celebration of Hidalgo's 1810 insurrection presented a significant public relations challenge to Porfirio Díaz, a man who had held power for more than thirty years and incarcerated his opponent prior to being re-elected during the centenary year. ${ }^{61}$ In the governmentsponsored historical procession, remember, it was Iturbide's victorious entry into Mexico City at the end of the War of Independence rather than Hidalgo's uprising that received top billing. And while Porfirian propaganda frequently counterposed Díaz with Juárez, and occasionally with Hidalgo, the general is completely absent in Posada's illustration. ${ }^{62}$ Below this revealing image is an amusing piece of doggerel eulogizing Hidalgo and mocking the Spanish king. Given the climate, it is not surprising that Spanish-owned businesses became a target for mob violence when the Mexican Revolution erupted a few months later.
Surprised and annoyed by news that the government was supporting an exhibition of Spanish painting, a group of young Mexican artists, including Orozco and headed by Gerardo Murillo, later known as Dr. Atl, decided to organize their own display of Mexican art in the National School of Fine Arts. The Porfirian government allocated 3,000 pesos, significantly less than the amount spent on the Spanish exhibition, to support this late addition to the centenary roster. The exhibition of Mexican artists also lacked a catalogue, but vintage photographs and research in the archives again allow a partial reconstruction of the display.63 Jorge Enciso's Anáhuac, a Náhuatl name for the valley of Mexico City meaning "place situated in the water," was one of several works depicting Indigenous subjects. The painting included in the background a large volcanic mountain, the expansive waters of Lake Texcoco, a majestic nopal cactus, and in front, an Indigenous figure in headdress and loincloth, welcoming the dawn of a new day. 64

Fausto Ramírez links modern Mexican painting to curricular reforms in drawing and a breakdown in the hierarchy of genres: by 1910, drawing had become both personal and expressive, and landscape and genre paintings were as popular as, if not more so than, history paintings. ${ }^{5}$ Even when painting a historical subject, Enciso explored the poetic rather than moralistic potential of his subject. Temporality was relative, past was fused with present (and future), and modern styles were used to portray traditional (American) subjects. The promise of mestizaje, a post-revolutionary ideal through which Indigenous and European citizens could create the new mixed race of a modern Mexican nation, is likewise nascent in such protorevolutionary works of art. Ricardo Gómez Robelo, writing specifically about Enciso's painting, compared the figure's dramatic gesture with

a triumphal salute to the light of the new day; one could say that as in Aztec ritual, [the figure] is praising the birth of a new year; even more significantly, the gesture is one of praise for la raza, the entire nation that beats within his heart. 66

Saturnino Herrán's La leyenda de los volcanes was also featured in the Mexican exhibition (fig. 12).67 Herrán's symbolist work combines a decorative approach to space and composition with a subject that breaks down the genre hierarchy separating myth and landscape. The painting depicts an Aztec legend, in which a beautiful white princess loves a dark-skinned Indian prince. Tricked by her disapproving father into believing that her beloved has been killed in battle, she dies of a broken heart. Upon his return, the grieving prince takes her body into the mountains, covers it with tears of snow and ice, and lies down beside her to die. The gods, taking pity on the lovers, turn them into Popocatépetl (smoking mountain) and Ixtaccíhuatl (white woman), two volcanic mountains visible from Mexico City. 


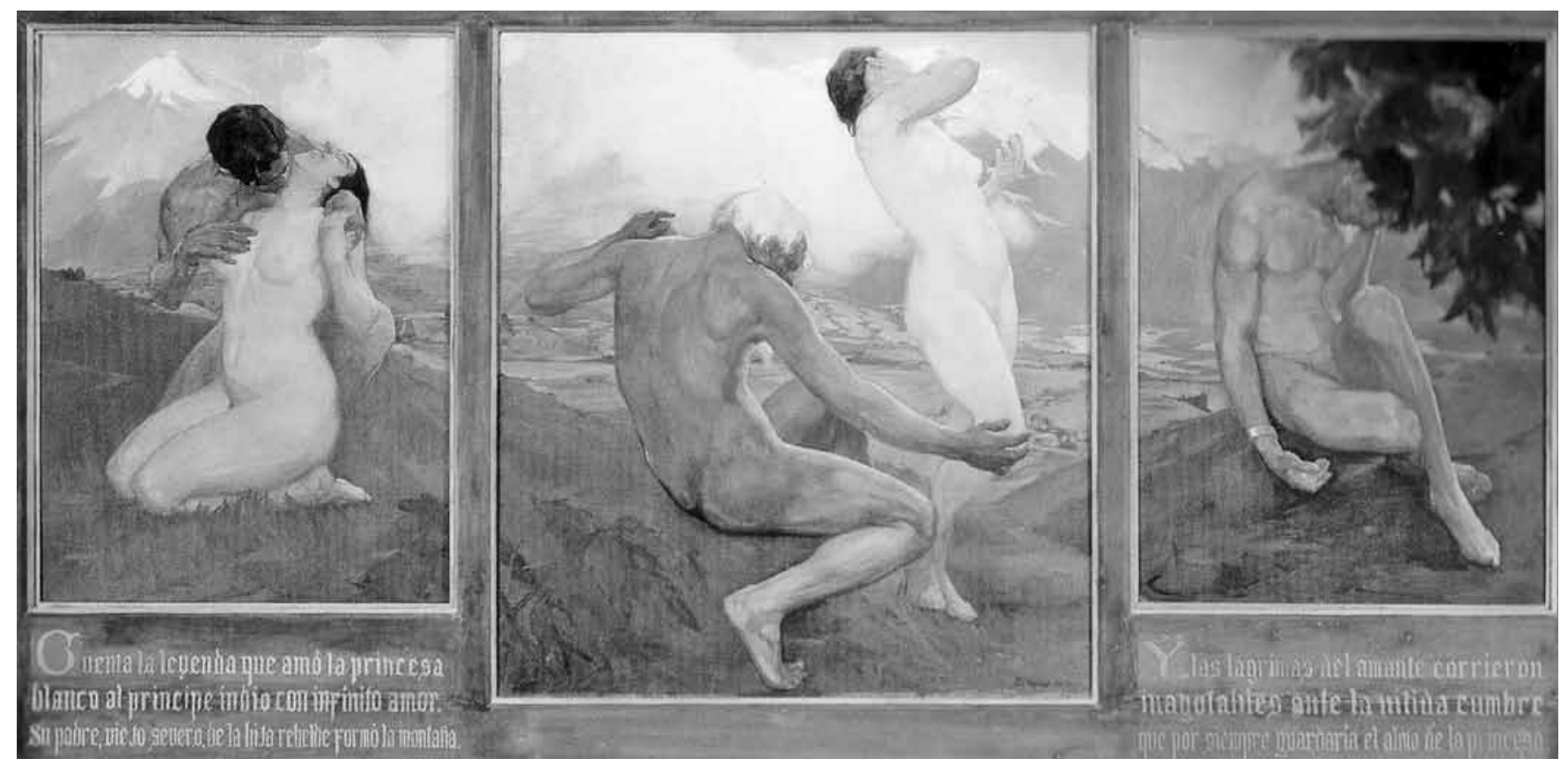

Figure 12. Saturnino Herrán, La leyenda de los volcanes, 1910. Oil on canvas, $147.5 \times 371.5 \mathrm{~cm}$. Pinacoteca del Ateneo Fuente, Saltillo, Coahuila (Photo: INBA).

Popocatépetl and Ixtaccíhuatl serve as metaphors for the Indigenous and European roots of the modern Mexican people. Herrán, however, uses a variation on the well-known legend, suggesting in the inscription on the wings of the triptych that the princess was turned into a mountain by her father rather than by the gods. In fact, the central male figure reads as both elderly patriarch, head capped like Porfirio Díaz by white hair, turning his rebellious daughter into a volcano, and also as recoiling prince, violently separated from his beloved, his head covered prophetically with tears turned into snowflakes. The inclusion of ear and wrist ornaments on the youthful prince in the panels at left and right, absent from the central male figure, differentiate young prince from elderly father; but the representation of the central figure as a heroic nude, with an outstretched hand that resembles and reaches toward the flaccid hand of the mourning prince at right, furthers the conflation of patriarch and lover.

The painting's narrative reads temporally from left to right, but it also reads like an altarpiece, with left and right wings framing a central transcendental image. The left and right panels of this modern retablo depict moments from before and after the transformation of the princess, while the large central panel suggests a spiralling "revolution" that brings narrative possibilities from the past, present, and future together into one. Herrán's visualization of the narrative fuses old age with youth and dramatically foregrounds the tragic union of Indigenous man and European woman. The power relationship that usually defines the darker, subordinate race as female (as in Chile's monument to Ercilla) is inverted, and the painting, especially when compared to official centenary posters that depicted the nation personified as a statuesque European woman clothed in white, stands as a richly layered allegory of contemporary politics and race in Mexico.68 The union depicted by Herrán obviously failed to produce children; after the Revolution, the mestizaje of la raza so eloquently predicted by Gómez Robelo became a founding principle of the modern Mexican nation.

\section{Toward a Transnational Art History}

To position the exhibition of Mexican art in direct opposition to the Spanish one, despite Orozco's caustic comment, would be overly simplistic. ${ }^{69}$ When teachers and students at the National School of Fine Arts were interviewed about the upcoming Spanish exhibition, they were uniformly enthusiastic, perceiving the presence of Spanish paintings in Mexico City to be beneficial for the development of art in their own country. Herrán, one of two students interviewed, expressed his "hope that the exhibition would be better than any other that has already been held in Mexico and do a lot of good for students in the academy." His classmate Francisco de la Torre went further, noting that the 
exhibition of Spanish painting would be of great importance for the teaching of art in Mexico as the art of this nation was "closely connected to art currents in Spain."70

Transnational study provides an opportunity to view cultural production from multiple perspectives, think through unsustainable binaries such as Spain and Latin America, and add crucial layers to our understanding of art, history, and culture. Patricia Clavin compares it to a honeycomb, one "that sustains and gives shape to the identities of nation-states, international and local institutions, and particular social and geographic spaces." A honeycomb, Clavin continues, both binds and contains "hollowed-out spaces where organisations, individuals and ideas can wither away to be replaced by new groups, people and innovations." 71 The fluidity of Clavin's model, one in which relations can change and mutate, is particularly appropriate when considering the histories of places, like Latin America, subject to colonization and its aftermath.

Cultural critic Gayatri Chakravorty Spivak was likewise searching for a new model when she called for the blending of Area Studies with Comparative Literature, aspiring to a field of inquiry that would combine the rigour of the one without the hegemonic prioritization of European culture found in the other. ${ }^{72}$ Studying Spanish art in Mexico need not re-assert the hierarchies of colonization. Listening to Mexican voices and looking at Mexican images in the context of the Spanish paintings exhibited at the 1910 centenary can help us to reveal, destabilize, and move beyond the binaries of colonization, deepening our appreciation for the cultural richness of this complex nation. In any event, by 1910 Spain had long since lost its position as a colonial power. Comparative examinations of Italian art in Argentina, or German art in Chile, should be equally fruitful: the small scale and picturesque subject of Arturo Gordon's wake for a small child, for example, begins an intriguing conversation with the work of German traveler-artist Johann Moritz Rugendas, who painted the local customs of Chile some eighty years earlier. And a study of the 1910 Japanese industrial arts exhibition and its connections to the decorative surface patterns that mark Jorge Enciso's Anábuac would deepen our understanding of Mexican culture (and of the Asian presence in Latin America more generally) even further.

The 1910 Spanish exhibitions in Buenos Aires, Santiago de Chile, and Mexico City emerged from vastly different histories, as well as from contemporary situations that varied politically, economically, and culturally. Although each country chose to include a Spanish exhibition in its centenary celebration, each had its own relationship to Spain. The similarities are intriguing as well, for what Spanish art offered these American nations was not simply a historical connection to Spain and a "renewal of the fraternal relations that shared blood and history demand," but also a strategy for making art of one's own. The creation of a modern national art during the first decades of the twentieth century concerned artists and cultural critics throughout the Americas. The Spanish paintings exhibited at the 1910 centenaries celebrated the particular costumbres of the Basque Country, Castile, and Valencia, among other regions of the Iberian peninsula. Artists in Latin America were eager to create their own Argentine, Chilean, or Mexican paintings, and like the Spanish, many turned to the regional particularities of place and traditions to do so. Local subjects, in other words, provided a visual language for the national in what was, by 1910, an increasingly globalized modern art world.

\section{Notes}

1 This essay is part of a larger project related to Spain and the American world's fairs, 1876 to 1915 . I use the term "American" in the broad, hemispheric sense. Many thanks to colleagues Mary Coffey, Rodrigo Gutiérrez Viñuales, Marco Katz, Soledad Novoa, James Oles, Fausto Ramírez, and Pedro Zamorano, as well as to research assistants Noelle Belanger, Heather Caverhill, and Fran Cullen. Oscar Vázquez kindly offered me an opportunity to present these ideas at the University of Illinois, and I received excellent manuscript suggestions from Aléna Robin, Luís de Moura Sobral, Joan Greer, and anonymous readers from RACAR. Support was provided by the Social Sciences and Humanities Research Council of Canada (SSHRC). Unless otherwise noted, translations are mine.

2 José Clemente Orozco: An Autobiography (1942; repr. and trans. Robert C. Stephenson. Mineola, NY, 2001), 28.

3 Patricia Clavin uses the word "honeycomb" in "Defining Transnationalism," Contemporary European History 14, 4 (November 2005): 421-39, a concept to which I return at the end of this essay.

4 Mauricio Tenorio-Trillo, Mexico at the World's Fairs: Crafting a Modern Nation (Berkeley, 1996); Álvaro Fernández Bravo, "Ambivalent Argentina: Nationalism, Exoticism, and Latin Americanism at the 1889 Paris Universal Exposition," Nepantla: Views from South 2, 1 (2001): 115-39; and Carmen Norambuena Carrasco, "Imagen de América Latina en la Exposición Universal de París de 1889," Dimensión Histórica de Chile 17-18 (2002-03): 87-121. Much of the information in these two paragraphs is derived from these excellent sources.

5 Benjamín Vicuña Mackenna, speaking in 1867; quoted in Norambuena Carrasco, "Imagen de América Latina," 103.

6 Colombia and Venezuela also celebrated in 1910. Ecuador celebrated from 1909 to 1922, Peru in 1921, Brazil in 1922, and Uruguay between 1925 and 1930. None of these other celebrations included exhibitions of Spanish paintings. See "Centenarios de la Independencia," special issue of Apuntes [Pontificia Universidad Javeriana, Bogotá] 19, 2 (July-December 2006): 169-316.

7 See Rodrigo Gutiérrez Viñuales, La pintura argentina: Identidad nacional e hispanismo, 1900-1930 (Granada [Spain], 2003), 107-61. 
8 See Jens Andermann, "Argentine Literature and the 'Conquest of the Desert', 1872-1896," http://www.bbk.ac.uk/ibamuseum/ texts/Andermann02.htm (accessed 16 April 2013).

9 Spanish participation at the Argentine centenary is documented by Francisco Camba and Juan Más y Pi, Los españoles en el Centenario Argentino (Buenos Aires, 1910).

10 Illustrated in Camba and Más y $\mathrm{Pi}$, Los españoles en el Centenario Argentino, 205, 207.

11 December 1909, printed pamphlet from the Cámara Oficial Española, Archivo del Ministerio de Asuntos Exteriores (AMAE), Madrid, Legajo 3208.

12 Ramón Gutiérrez, "El Pabellón Español en la Exposición del Centenario Argentino," Quintana 8 (2008): 45-57.

13 Letter from the Cámara Oficial Española to the Ministro de Estado, 28 September 1917, AMAE, Legajo 3208. See also Ramón García-Rama, "Historia de una emigración artística," in Otros Emigrantes: Pintura española del Museo Nacional de Bellas Artes de Buenos Aires (Madrid, 1994), 17-43.

14 Exposición Internacional del Centenario (Buenos Aires, 1910).

15 "Exposición Internacional de Arte: Lista de los importes totales de las obras vendidas en las diversas secciones," Athinae III, 3 (February 1911): 25-29.

16 Tenorio-Trillo, Mexico at the World's Fairs, 112-23, and Beatriz González-Stephan, "Showcases of Consumption: Historical Panoramas and Universal Expositions," in Beyond Imagined Communities: Reading and Writing the Nation in NineteenthCentury Latin America, ed. Sara Castro-Klarén and John Charles Chasteen (Baltimore, 2003), 225-38.

17 On the 1910 structure, see Alicia Rovere and Marta Sandller, "La actuación de la Sociedad Central de Arquitectos en las celebraciones del Centenario de la Revolución de Mayo de 1810," Universidad de Buenos Aires, May 2010, online at http://biblioteca.fadu.uba.ar/ tiki/tiki-index.php?page=revista-tecnica (accessed 20 June 2012).

18 Thanks to Jennifer Greenhill for helping clarify this point.

19 On Zuloaga, see Enrique Lafuente Ferrari, La vida y la obra de Ignacio Zuloaga (3rd ed., Barcelona, 1990).

20 See Donald L. Shaw, The Generation of 1898 in Spain (London, 1975); José Álvarez Junco and Adrian Shubert, eds., Spanish History Since 1808 (London, 2000); and José Álvarez Junco, Spanish Identity in the Age of Nations (Manchester, 2011).

21 See García-Rama, "Historia de una emigración artística," 17-43, and Roberto Amigo, "El arte español en la Argentina, entre el mercado y la política," in El arte español en la Argentina, 1890-1960, ed. Patricia Artundo and Roberto Amigo Cerisola (Buenos Aires, 2006), 17-50.

22 In a letter dated 9 April 1909, Artal expressed anger about the small number of paintings Sorolla was sending to him and about their quality. A photocopy of this letter is in the Fundación Espigas, Buenos Aires. The literature on Joaquín Sorolla y Bastida is extensive; in English, see Edmund Peel et al., The Painter Joaquin
Sorolla y Bastida (London, 1989) and José Luis Díez and Javier Barón, Joaquin Sorolla, 1863-1928 (Madrid, 2009).

23 Zuloaga initially expressed doubts about exhibiting in Argentina, but eventually changed his mind. Mariano Gómez de Caso Estada, ed., Correspondencia de Ignacio Zuloaga con su tio Daniel (Segovia, 1992), 270.

24 Rodrigo Gutiérrez Viñuales, "La pintura Argentina y la presencia de Ignacio Zuloaga (1900-1930)," in Cuadernos Ignacio Zuloaga 2 (2000): 27-46.

25 For this reason, Artal returned a gypsy painting to Sorolla and asked for something else. 1 July 1904, Typescript in the Fundación Espigas, Buenos Aires.

26 Augusto Gozalbo, "Hermen Anglada y Camarasa," Athinae III, 31 (March 1911): 65.

27 See, for example, Godofredo Daireaux, "La Exposición I. de Arte: Impresiones," Athinae III, 23 (July 1910): 10.

28 Rodrigo Gutiérrez Viñuales, "Hermen Anglada Camarasa y Mallorca: Su significación para el arte iberoamericano," in El arte español del siglo XX: Su perspectiva al final del milenio, ed. Miguel Cabañas Bravo (Madrid, 2001), 189-203.

29 Ignacio Gutiérrez Zaldívar, Quirós (Buenos Aires, 1991) and Gutiérrez Zaldívar, 100 pintores del arte de los argentinos, 1799 2006 (Buenos Aires, 2006).

30 Carlos Giambiagi, "Las costumbres nacionales en el arte," Athinae III, 22 (June 1910): 23.

31 Macarena Ibarra, "El centenario: ¿Un mito urbano? Santiago de Chile, 1887-1910," Bicentenario 4, 1 (2005): 152-60.

32 José Enrique Rodó, El Centenario de Chile (repr., Montevideo, 1975), n.p.

33 Of European immigrants, $33 \%$ went to Brazil, $14 \%$ to Cuba, and $4 \%$ to Uruguay. Paula de Dios Crispi, Inmigrar en Chile: Estudio de una cadena migratoria hispana (Santiago de Chile, 1993), 18-37.

34 The "pacification of Araucanía" continued into the early 1880s, when the few remaining Indigenous Mapuche were forcibly resettled on reducciones, or reserves, in the south. On the oppression of Chile's Indigenous population, see José Bengoa, Historia del pueblo mapuche, siglo XIX y XX (Santiago de Chile, 1985).

35 "Monumentos ofensivos," Zig-Zag 6, 279 (25 June 1910): n.p.

36 Exposición Internacional de Bellas Artes de 1910; Catálogo oficial ilustrado (Santiago de Chile, 1910).

37 On Álvarez de Sotomayor, see Pedro Emilio Zamorano Pérez, El pintor F. Álvarez de Sotomayor y su huella en América (La Coruña, 1994) and José Carlos Valle Pérez et al., Fernando A. de Sotomayor (Pontevedra, 2004).

38 Zamorano Pérez, El pintor F. Álvarez de Sotomayor, 158-66.

39 Alberto Mackenna Subercaseaux, Luchas por el arte (SantiagoValparaiso, 1915), 56.

40 Mackenna, Luchas, 56-58. Rafael Errázuriz Urmeneta commissioned portraits of his family and decorative panels for his mansion in Santiago early in Sorolla's career. 
41 The government allocated 400,000 francs for this purpose. Letter from Mackenna, 8 January 1911. "Obras," volume 8, Archivo Documental, Museo Nacional de Bellas Artes, Biblioteca y Centro de Documentación, Santiago de Chile (AD, MNBA, BCDS). A list of the works acquired for the museum is included in "Exposición en Homenaje al Centenario 1910," volume 10, AD, MNBA, BCDS. See also Alfonso Pérez Sánchez, Pintura española en Chile: Colección de pintura española del Museo Nacional de Bellas Artes de Santiago de Chile (Madrid, 1999).

42 “Exposición en Homenaje al Centenario 1910," volume 10, AD, MNBA, BCDS.

43 Richon Brunet, "El arte en Chile," in Exposición Internacional de Bellas Artes de 1910, 36.

44 La generación del trece, a name paying tribute to an exhibition of works by these artists held in 1913, is also used to describe this group.

45 On Gordon and the generación del centenario, see Ricardo Bindis, Pintura Chilena 200 años (Santiago, 2006), 176-205.

46 Figures according to Jacques Lafaye, "Historical Differences: Caste Society in New Spain," in La pintura de castas (Mexico City, 1990), n.p.

47 Porfirio Díaz joined the military in 1846 , rose to the rank of general, and was elected president of Mexico in 1884. He remained in power for almost three decades, until the outbreak of the Mexican Revolution. See Alan Knight, The Mexican Revolution, 2 vols. (New York, 1986).

48 Mauricio Tenorio-Trillo makes this point in I Speak of the City: Mexico City at the Turn of the Twentieth Century (Chicago, 2012), 8-10. See also Annick Lempérière, "Los dos centenarios de la independencia mexicana, 1910-1921: De la historia patria a la antropología cultural," Historia Mexicana 45, 2 (October-December 1995): 317-52; Mauricio Tenorio-Trillo, "1910 Mexico City: Space and Nation in City of the Centenario," Journal of Latin American Studies 28 (February 1996): 75-104; and Michael J. Gonzales, "Imagining Mexico in 1910: Visions of the Patria in the Centennial Celebration of Mexico City," Journal of Latin American Studies 39, 3 (2007): 495-533.

49 See Lampérière, "Los dos centenarios," 325-27, and Gonzales, "Imagining Mexico in 1910," 497, 499, and 513-14.

50 “Gran exposición de arte español," El Imparcial, 21 May 1910, 1.

51 Gonzales provides complementary financial information on centenary expenditures in "Imagining Mexico in 1910," 504-08. See also Memoria de los trabajos emprendidos y llevados a cabo por la comisión n. del centenario de la independencia (Mexico City, 1910).

52 Silvia Seligson, "La exposición japonesa: Presencia japonesa en la celebración del primer centenario de independencia," in 1910: El arte en un año decisivo: Exposición Española - Exposición Japonesa (Mexico City, 1991), 33-44. This catalogue is one of two devoted to art at the centenary. See also 1910, El arte en un año decisivo: $L a$ Exposición de Artistas Mexicanos (Mexico City, 1991).
53 Angélica Velázquez Guadarrama, "La Exposición Española de Arte e Industrias Decorativas de 1910," en 1910: El arte en un año decisivo, 7-30.

54 “La exposición de arte español," El Heraldo Mexicano, 29 October 1910, 3; quoted in Xavier Moyssén, La crítica de arte en México, 1896-1921 (Mexico City, 1999), 448.

55 Seligson, "La exposición japonesa," 38.

56 See Tenorio-Trillo, "1910 Mexico City," 101, and Earle, “Padres de la Patria' and the Ancestral Past: Commemorations of Independence in Nineteenth-Century Spanish America," Journal of Latin American Studies 34 (November 2002): 805.

57 See Alfonso Pérez Sánchez, Pintura española en el Museo Nacional de San Carlos (Valencia, 2000).

58 John Mraz discusses the Porfirian press in Looking for Mexico: Modern Visual Culture and National Identity (Durham, 2009), 42-58.

59 "El centenario de la independencia mejicana," El Correo Español, 1 September 1910, 1.

60 Both the DeGolyer Library and the Art Institute of Chicago attribute this print to Posada. On Posada, see Patrick Frank, Posada's Broadsheets: Mexican Popular Imagery, 1890-1910 (Albuquerque, 1998) and Diane Helen Miliotes, José Guadalupe Posada and the Mexican Broadside (Chicago, 2006).

61 Lampérière makes this point in "Los dos centenarios," 325-27.

62 When Hidalgo and Díaz were juxtaposed, Díaz was usually positioned as the culminating figure of Mexican development. Souvenir postcards, for example, depicted Hidalgo as the initiator, flanked by Juárez the liberator and Díaz the builder. Thanks to Fausto Ramírez for providing reproductions of ephemera produced for the Mexican centenary.

63 See Genaro García, Crónica oficial de las fiestas del primer centenario de México (Mexico City, 1911).

64 The painting, now lost, is visible in a photograph in 1910: El arte en un año decisivo, 74.

65 Fausto Ramírez, "Hacia la gran exposición del Centenario de 1910: El arte mexicano en el cambio de siglo," in 1910: El arte en un año decisivo, 19-63.

66 Quoted in Ramírez, "Hacia la gran exposición," 36.

67 On Herrán, see Sandra Benito Vélez et al., Saturnino Herrán; Instante subjetivo (Mexico City, 2010).

68 For Alfredo Híjar y Haro's official centenary poster, see Xavier Guzmán-Urbiola et al., Parafernalia e independencia (Mexico City, 2010), 125.

69 Pilar García de Germenos likewise makes this point in "Exposición de los artistas mexicanos de 1910," in 1910: El arte en un año decisivo, 70 .

70 "La exposición de arte español: Opinan los maestros y artistas mexicanos," El Imparcial, 30 May 1910, 1.

71 Patricia Clavin, "Defining Transnationalism," 421.

72 Gayatri Chakravorty Spivak, Death of a Discipline (New York, 2003). 